MARINA DE DEUS MOURA DE LIMA

CORRELAÇÃO ENTRE A PRESENÇA DO HPV NA BOCA E NO COLO UTERINO DE PACIENTES COM SOROLOGIA POSITIVA E NEGATIVA PARA O HIV 
Marina de Deus Moura de Lima

\section{Correlação entre a presença do HPV na boca e no colo uterino de pacientes com sorologia positiva e negativa para o HIV}

Tese apresentada à Faculdade de Odontologia da Universidade de São Paulo para obter o título de Doutora, pelo Programa de Pós-Graduação em Odontologia.

Área de Concentração: Patologia Bucal

Orientadora: Profạ. Drạ. Marina H. C. G. de Magalhães

São Paulo 
Lima, Marina de Deus Moura de

Correlação entre a presença do HPV na boca e no colo uterino de pacientes com sorologia positiva e negativa para o HIV/ Marina de Deus Moura de Lima; orientador Marina H. C. G. de Magalhães. -- São Paulo, 2009.

94p.; fig., tab.; graf.; $30 \mathrm{~cm}$.

Tese (Doutorado - Programa de Pós-Graduação em Odontologia. Área de Concentração: Patologia Bucal) -- Faculdade de Odontologia da Universidade de São Paulo.

1. Papillomavirus - HIV - Relação 2. Mucosa oral - Papillomavirus - HIV 3. Colo uterino - Papillomavirus - HIV 4. Patologia bucal

CDD 617.63

BLACK D61

AUTORIZO A REPRODUÇÃO E DIVULGAÇÃO TOTAL OU PARCIAL DESTE TRABALHO, POR QUALQUER MEIO CONVENCIONAL OU ELETRÔNICO, PARA FINS DE ESTUDO E PESQUISA, DESDE QUE CITADA A FONTE E COMUNICADA AO AUTOR A REFERÊNCIA DA CITAÇÃO.

São Paulo,

Assinatura:

E-mail: 


\section{FOLHA DE APROVAÇÃO}

Lima MDM. Correlação entre a presença do HPV na boca e no colo uterino de pacientes com sorologia positiva e negativa para o HIV [Tese de Doutorado]. São

Paulo: Faculdade de Odontologia da USP; 2009.

São Paulo,

\section{Banca Examinadora}

1. $\operatorname{Prof}(a) \cdot \operatorname{Dr}(a)$.

Titulação:

Julgamento:

Assinatura:

2. $\operatorname{Prof}(\mathrm{a}) \cdot \operatorname{Dr}(\mathrm{a})$.

Titulação:

Julgamento:

Assinatura:

3. $\operatorname{Prof}(a) \cdot \operatorname{Dr}(a)$.

Titulação:

Julgamento:

Assinatura:

4. $\operatorname{Prof}(a) \cdot \operatorname{Dr}(a)$.

Titulação:

Julgamento:

Assinatura:

5. $\operatorname{Prof}(a) \cdot \operatorname{Dr}(a)$.

Titulação:

Julgamento:

Assinatura: 


\section{DEDICATÓRIA}

Ao meu marido Carlos Eduardo, por todo o amor, companheirismo, apoio e participação ativa na estatística desta tese;

Aos meus pais, Wagner e Lúcia, exemplos de dignidade e professores altamente competentes, vocês são minha inspiração. Muito obrigada por me ensinarem o valor do estudo, pela oportunidade de chegar até aqui, pelo amor, apoio e confiança;

Aos meus irmãos, Rafael e Isabela, sempre muito presentes em minha vida, muito obrigada pela amizade que sempre partilhamos; 


\section{AGRADECIMENTOS ESPECIAIS}

À minha querida orientadora Professora Doutora Marina Magalhães, exemplo de vida, de profissionalismo e de amor à ciência. Agradeço pela disponibilidade irrestrita e orientação segura, crítica e criativa, fatos que desenvolveram em mim o senso crítico e vontade de acertar em minhas propostas de vida. O meu reconhecimento e gratidão, inclusive pela amizade demonstrada ao longo de nossa convivência. Muito obrigada pela orientação desse trabalho;

À Professora Doutora Andrea Mantesso, por ter me acolhido na Disciplina Patologia Bucal e por ter me orientado de forma tão segura durante o mestrado. Foi você que sedimentou em mim o amor à pesquisa. Muito obrigada por todo o conhecimento transmitido e pela amizade construída,

À professora Karem Ortega por ter me apoiado em várias etapas desse trabalho;

À Dra Catalina Riera Costa, por ter disponibilizado o acesso ao Centro de Referência e Treinamento em DST-AIDS e possibilitado a realização desse trabalho, a minha eterna gratidão; 
À Dra Sônia Maria Miranda Pereira, pela participação ativa na execução deste trabalho, permitindo a execução dos experimentos práticos no Instituto Adolfo Lutz. 


\section{AGRADECIMENTOS}

À Professora Doutora Suzana Cantanhede Orsini Machado de Sousa, admirável mestra e pesquisadora, agradeço pelos ensinamentos e generosidade na transmissão de conhecimentos.

Aos Professores Doutores Décio dos Santos Pinto Júnior, Marília Trierveiler Martins, Fábio Daumas Nunes, cujos ensinamentos foram fundamentais para a minha formação;

Às Médicas Ginecologistas do Centro de Referência e Treinamento em DST-AIDS Ariane de Castro Coelho e Patrícia Tomé Hernandes cujas participações foram imprescindíveis na realização desta pesquisa.

À Luciana Aguiar, pela execução da captura híbrida, tarefa que requereu dedicação, capricho e minúcia.

À minha grande amiga Yonara Maria Freire Soares Marques, pela amizade e apoio em muitos trabalhos e momentos inesquecíveis de vida compartilhados. Você é uma pessoa iluminada e muito especial. 
À minha amiga Flávia Caló de Aquino Xavier, pessoa especial e muito amada, pela amizade, convívio dentro e fora da Faculdade. O seu apoio foi fundamental na concretização deste trabalho;

Às amigas Aluana Dal Vecchio e Fernanda Giudice, pelo apoio fundamental na finalização deste trabalho.

À Kívia Ferrazzo, uma grande amiga e exemplo de profissional, obrigada pelos agradáveis momentos e experiências de vida compartilhados;

À minha família em São Paulo, Rafael, Carla, Mônica, Pedro, Newton, Andressa, Ana Patrícia e Sara, muito obrigada por todos os bons momentos que compartilhamos juntos,

Aos meus amigos da Disciplina de Patologia Bucal: Érika Pereira, Fernanda Yamamoto, Fábio Coracín, Tessa Botelho, Fernanda Giudice, Paulo Santos, Valtuir Félix, Brunno Santos, pelo agradável convívio.

A todos os colegas do curso de Pós-Graduação, pelo compartilhamento de experiências e saudável convívio, sentirei saudades. 
Às funcionárias Elisa Santos e Edna Toddai (in memorian), com as quais vivi momentos de agradável, sincero e produtivo convívio;

Agradeço de coração à atenção das funcionárias Zilda, Néia, Bia e Nair;

Aos funcionários do Centro de Referência e Treinamento em DST-AIDS: Antônio, Selma, Andrea, Nina, Márcia, Elbe, Roseli e Marilda, que me acolheram de forma tão carinhosa e que me auxiliaram na seleção dos pacientes deste experimento;

À bibliotecária da USP, Glauci, pela fundamental contribuição na revisão desta tese;

À Camila Guindalini, muito obrigada pelo excelente trabalho quando da realização da análise estatística;

\section{À Fundação de Amparo à Pesquisa do Estado de São Paulo (FAPESP) pelo auxílio financeiro que tornou possível a realização da pesquisa;}

Quando mencionamos nomes, incorremos no risco de esquecer alguém e, por isso, quero agradecer a todos que, embora não tenham sido mencionados, estiveram presentes comigo durante este percurso, muitos de forma direta e outros de maneira indireta. 
Lima MDM. Correlação entre a presença do HPV na boca e no colo uterino de pacientes com sorologia positiva e negativa para o HIV [Tese de Doutorado]. São Paulo: Faculdade de Odontologia da USP; 2009.

\section{RESUMO}

A infecção genital pelo papilomavírus humano (HPV) corresponde a uma das doenças sexualmente transmissíveis mais frequentes no mundo. Uma preocupação dos pacientes que apresentam HPV na região anogenital diz respeito à possibilidade de disseminação desse vírus para outras partes do corpo. O objetivo geral desse estudo foi avaliar a possível correlação existente entre infecções pelo HPV na mucosa oral e no colo uterino em mulheres com sorologias positiva e negativa para - HIV. Pretendeu-se, também, identificar variáveis clínicas, demográficas e laboratoriais associadas à infecção oral pelo HPV. A amostra foi constituída por 200 pacientes do gênero feminino, sendo 100 com sorologia positiva para HIV (grupo 1) e 100 com sorologia negativa para HIV (grupo 2). As pacientes foram incluídas consecutivamente no Centro de Referência e Treinamento em DST-AIDS entre abril de 2008 a maio de 2009. Todas as pacientes assinaram um Termo de Consentimento Livre e Esclarecido e responderam a uma ficha com questionamentos sobre hábitos e comportamento sexual. Além disso, tiveram as cavidades oral e ginecológica examinadas, sendo que células superficiais de ambos os locais foram coletadas e avaliadas pela captura híbrida 2 e pela citologia em base líquida. Para comparação de variáveis qualitativas, como freqüências e proporções, foi utilizado o teste de qui-quadrado ou exato de Fisher, se necessário. Para comparação de dados quantitativos, foram utilizados os testes de Mann-Whitney ou t de Student. A análise multivariada foi executada utilizando-se o teste de regressão 
logística, sendo que o valor de significância estatística estabelecido foi de $5 \%$ $(p<0,05)$. O DNA do HPV foi detectado nas amostras cervicais de $41 \quad(41 \%)$ pacientes HIV+ e de 45 (45\%) HIV- $(p=0.67)$. Nas amostras da cavidade oral, o DNA do HPV foi observado em 11 mulheres do G1 (HIV+) e em 2 mulheres do G2 (HIV-) (OR=6,06; $95 \% I C=1,31-28,07 ; p=0,02)$. Os subtipos oncogênicos foram prevalentes em ambos os grupos, sendo que não foi observada diferença entre os grupos $(\mathrm{p}=0.87)$. Nenhuma paciente apresentou lesão macroscópica oral relacionada ao HPV, sendo que 15 (15\%) mulheres do G1 (HIV+) e 17 (17\%) do G2 (HIV-) apresentaram lesão macroscópica na região genital $(p=0.2129)$. Com os resultados obtidos pôde-se concluir que nesta população não houve correlação entre a infecção pelo HPV nas mucosas oral e cervical. Além disso, as pacientes HIV+ apresentaram maior prevalência de infecção pelo DNA-HPV na boca em comparação às pacientes HIV-.

Palavras-Chave: HPV, HIV, mucosa oral, mucosa cervical, correlação 
Lima MDM. Correlation between oral and cervical human papillomavirus infection in HIV+ and HIV- patients [Tese de Doutorado]. São Paulo: Faculdade de Odontologia da USP; 2009.

\section{ABSTRACT}

Human papillomavirus (HPV) is one of the most prevalent sexually transmitted viruses worldwide with both oral and genital manifestations. The high prevalence of HPV infection among HIV + individuals provides an opportunity to elucidate the relationship between oral and cervical HPV-infection in this group of subjects. The aim of this study is to evaluate the possible association between oral and cervical infections in HIV-positive and negative patients. One hundred HIV+ (group 1) and 100 HIV- (group 2) women were recruited consecutively from a gynecologic clinic between April 2008 and May 2009. All subjects were given a cervical and oral examination. Cytological samples were evaluated by the hybrid capture 2 technique from oral and cervical scrapings. Statistical analysis was performed using chi-square test and $p$ values $<0.05$ were considered significant. HPV-DNA was detected in cervical scrapings from 41 (41\%) HIV-positive subjects and from 45 (45\%) HIVnegative subjects $(p=0.67)$. In oral samples, HPV-DNA was observed in 11 subjects from group 1 and in 2 subjects from group $2(p=0.02)$. High-risk HPV subtypes were prevalent in both groups and no difference between the groups was detected $(\mathrm{p}=0.87)$. No subject showed macroscopic oral HPV-related lesion, whereas 15 (15.00\%) from group 1, and 17 (17.00\%) from group 2, presented with macroscopic genital lesion $(p=0.2129)$. HPV-DNA was more frequent in oral mucosa of HIV+ patients than HIV- $(p=0,018)$. There was no association between oral and cervical 
HPV infection in HIV+ and HIV- patients. Presence of cervical lesion was not associated with oral lesion.

Keywords: HPV, oral, cervical, correlation, HIV 


\section{LISTA DE ABREVIATURAS E SIGLAS}

AIDS Síndrome da imunodeficiência adquirida

CASI-D células atípicas de significado indeterminado, não sendo possível afastar lesão de alto grau

CASI células atípicas de significado indeterminado, possivelmente não neoplásicas

Ca carcinoma epidermóide

céls células

CD4 linfócitos T CD4+

$\mathrm{CH} 2 \quad$ captura híbrida 2

cm centímetro

CMV citomegalovírus

CV carga viral

DST doença sexualmente transmissível

DNA ácido desoxirribonucléico (deoxyribonucleic acid) 
DNA-HPV DNA do HPV

E

genes de transcrição precoce

E5

proteína E5 do HPV

E6

proteína E6 do HPV

E7

proteína E7 do HPV

EDTA "Etylenediamine tetraacetic acid"

et al. e colaboradores

g

grama

G1

$1^{\text {a }}$ parada do ciclo celular

G2

$2^{\underline{a}}$ parada do ciclo celular

HAART terapia antiretroviral altamente ativa

HIV vírus da imunodeficiência adquirida

HIV+ $\quad$ sorologia positiva para HIV

HIV- $\quad$ sorologia negativa para HIV

HPV papilomavírus humano (human vírus papillomavirus) 

$k \mathrm{D}$
kilo-daltons
$\mathrm{L}$
genes de transcição tardia
LCR
região de controle longa do HPV
LIAG
lesão intra-epitelial de alto-grau de malignidade
LIBG lesão intra-epitelial de baixo grau de malignidade
ml mililitro
$\mu \mathrm{l} \quad$ microlitro
$\mathrm{mm}^{3} \quad$ milímetros cúbicos
$\mu \mathrm{m} \quad$ micrômetro
$\mu \mathrm{g} \quad$ micrograma
nm nanômetro
pg picograma
PCR reação em cadeia da polimerase
p53 gene p53
$\mathrm{pRb} \quad$ proteína retinoblastoma 
$\mathrm{pH} \quad$ potencial hidrogeniônico

$\mathrm{Rb} \quad$ gene retinoblastoma

RNA ácido ribonucléico (ribonucleic acid)

Rpm rotações por minuto

S período de síntese do DNA

TA temperatura ambiente

UCM Universal Collection Medium

USA "United States of América"

USP Universidade de São Paulo 


\section{LISTA DE SÍMBOLOS}

$\%$ por cento

${ }^{\circ} \mathrm{C}$ graus Celsius

um micrômetro

$x$ vezes

+ mais / positivo

- menos / negativo 


\section{SUMÁRIO}

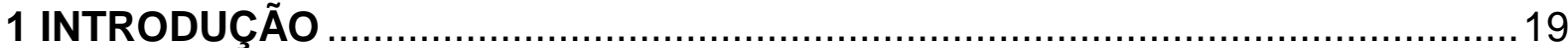

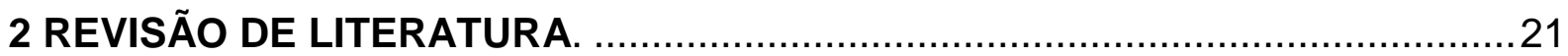

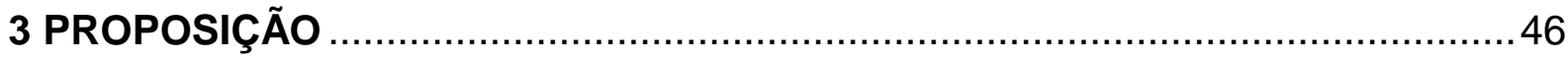

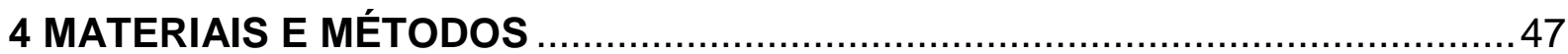

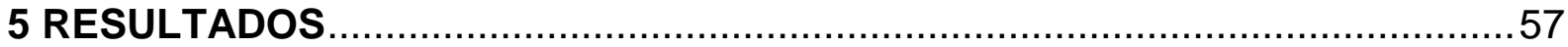

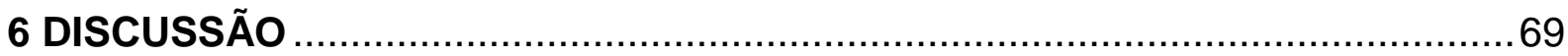

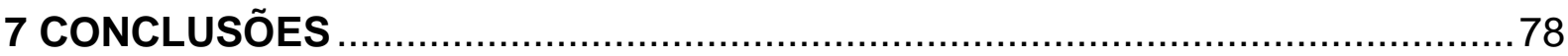

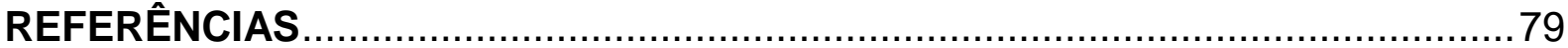

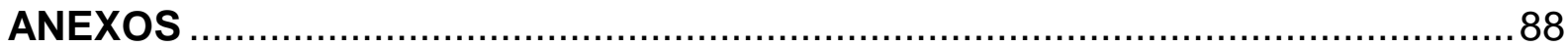




\section{INTRODUÇÃO}

O papilomavírus humano (HPV) é um patógeno intracelular associado ao desenvolvimento de lesões na pele e nas mucosas oral, genital e anal. Mais de 120 subtipos de HPV já foram identificados e, de acordo com seu potencial oncogênico, são classificados como de alto ou baixo risco (CAMPISI et al., 2007). De todos os subtipos de HPV identificados, pelo menos 30 já foram localizados em lesões orais benignas e malignas (SYRJÄNEN, 2003).

Estudos epidemiológicos têm demonstrado a infecção pelo HPV como um importante fator de risco para o desenvolvimento de lesões neoplásicas, tanto de colo uterino quanto da orofaringe (FURRER et al., 2006; GILLISON et al., 2000; OSTWALD et al., 2003). A via de contágio mais frequente é a sexual, porém existem relatos de transmissão vertical e auto-contaminação (CAMPISI; GIOVANELLI, 2009).

A maioria dos estudos sobre infecção pelo HPV refere-se a indivíduos imunocompetentes. Entretanto, alguns trabalhos demonstram que os pacientes com sorologia positiva para o vírus da imunodeficiência humana (HIV) apresentam risco aumentado para infecção anogenital e oral pelo HPV (JAMIESON et al., 2002; KREIMER et al., 2004; PALEFSKY, 2006).

A detecção direta dos genomas do HPV e dos seus transcritos pode ser obtida através de procedimentos que incluem imunoistoquímica, hibridizações (Southern blot, Northern blot, dot blot e in situ), reação em cadeia da polimerase (PCR), captura híbrida $(\mathrm{CH})$ e sequenciamento de DNA. A CH e a PCR são os 
métodos mais amplamente utilizados atualmente e que apresentam maiores sensibilidade e especificidade (MILLER; JOHNSTONE, 2001).

Muitos aspectos concernentes à inter-relação entre as infecções oral e genital pelo HPV ainda permanecem desconhecidos. A infecção pelo HPV desencadeia impacto psicológico negativo nos pacientes acometidos, principalmente no que diz respeito à auto-contaminação e à possibilidade de transmissão desse vírus para outras partes do corpo.

O objetivo do presente estudo foi avaliar a correlação entre a presença de HPV na boca e no colo uterino de mulheres com sorologia positiva e negativa para o HIV atendidas em centro de referência para tratamento de DST-AIDS. 


\section{REVISÃO DA LITERATURA}

Visando a uma melhor compreensão, a revisão da literatura será dividida em tópicos.

\subsection{Biologia do HPV}

O papiloma vírus humano (HPV) pertence à família do papovavírus, apresentando DNA circular, pequeno (55nm), não envelopado, icosaédrico, de 9 kD, com tropismo por células epiteliais (HA; CALIFANO, 2004; HENESSEY; WESTRA; CALIFANO, 2009).

O genoma do HPV pode ser dividido em uma região de controle longa (LCR), compreendendo cerca de $10 \%$ do genoma e uma região onde se encontram os genes de transcrição precoce $(E)$ e tardia $(L)$. O alinhamento das seqüências de DNA do HPV revela uma organização genética de regiões que codificam proteínas virais. Essas estão presentes em uma só fita de DNA e suas funções foram apontadas em parte pela comparação com a estrutura do papilomavírus bovino tipo 1, o qual foi extensivamente caracterizado em linhagens celulares de camundongos geneticamente transformados. Em geral, os genes E são expressos logo após a infecção e codificam as proteínas envolvidas na indução e regulação da síntese do DNA. Por contraste, os genes L são expressos em estágios posteriores da infecção e codificam as proteínas do capsídeo viral. Os genes E são subdivididos em E1 a 
E7, e os genes L, em L1 e L2. Do ponto de vista da transformação celular, os genes E5, E6 e E7 são os mais importantes (HENESSEY; WESTRA; CALIFANO, 2009).

O HPV é um vírus de DNA epiteliotrópico que tem a pele e as mucosas como principais sítios de infecção (OLIVEIRA et al., 2003). Mais de 120 diferentes tipos de HPV já foram identificados, sendo que aproximadamente $1 / 3$ infecta células epiteliais do trato genital. Eles são classificados como de alto ou baixo risco, de acordo com o potencial de oncogênese, ou seja, capacidade de induzir transformação neoplásica (CAMPISI; GIOVANELLI, 2009). Mais de 30 subtipos já foram identificados em lesões orais: $1,2,3,4,6,7,10,11,13,16,18,20,28,31,32,33,35,38,40,45,52$, $54,55,57,58,59,68,69,72,73,77,85$ (SYRJÄNEN, 2003). Desses, quatro são particularmente importantes, os subtipos 6 e 11, que são relacionados a lesões benignas do epitélio oral e 16 e 18, comprovadamente carcinogênicos em colo uterino e possivelmente envolvidos na etiologia de determinados carcinomas epidermóides orais (OLIVEIRA et al., 2003). É importante citar que em pacientes imunossuprimidos, é comum que se encontrem múltiplos e incomuns tipos de HPV em uma única lesão (SYRJANËN, 2003).

\subsection{Mecanismos de infecção e replicação}

O HPV tem o potencial de infectar células da camada basal do epitélio quando existe solução de continuidade da superfície, sendo que grande parte das infecções é eliminada pelo sistema imune, não resultando em doença clínica. Quando o sistema imunológico não consegue barrar a invasão do vírus, o mesmo 
permanece latente no núcleo das células infectadas (HORMIA et al., 2005; HENESSEY; WESTRA; CALIFANO, 2009). A replicação do HPV ocorre nas células das camadas basal e parabasal do epitélio, locais em que apenas genes precoces são transcritos. Multiplicação extensiva do DNA viral e transcrição de todos os genes virais, bem como a formação de capsídeo, ocorrem apenas nas camadas mais superficiais do epitélio, formando inclusões eosinofílicas e uma degeneração celular característica (BUSTOS et al., 2001), com a formação de halos perinucleares; além de grande quantidade de alterações histológicas, como a presença de células superficiais com atipias nucleares de tamanho e forma (HA; CALIFANO, 2004).

\subsection{Manifestações clínicas}

A infecção pelo HPV é uma das doenças sexualmente transmissíveis mais prevalentes no mundo, aparecendo associada à grande variedade de lesões epiteliais proliferativas (OSTWALD et al., 2003).

As mulheres são mais susceptíveis aos efeitos oncogênicos do HPV na região genital e no colo uterino (PAAVONEN, 2007). Estudos epidemiológicos sugerem que aproximadamente $80 \%$ das mulheres apresentam HPV genital aos 50 anos de idade (GRAVITT; JAMSHIDI, 2005). As características anatômicas do trato genital feminino, principalmente a histologia da mucosa podem justificar em parte a vulnerabilidade do gênero feminino. O câncer de colo uterino é o segundo mais frequente entre mulheres, sendo que $80 \%$ dos novos casos ocorrem em países em desenvolvimento (SCHIFFMAN et al., 2007). 
Na região oral, os HPV classificados como de baixo grau oncogênico, como 6 e 11 são os mais freqüentemente detectados em lesões orais benignas tais como verruga vulgar, condiloma acuminado, papiloma e hiperplasia epitelial focal. Os subtipos de alto grau oncogênico, como o 16 e 18, ao contrário, estão fortemente associados com carcinomas epidermóides e com lesões cancerizáveis com alto risco de transformação maligna (D’SOUZA et al., 2007a).

A relação causal entre o consumo de álcool e tabaco e o desenvolvimento de carcinoma epidermóide está bem estabelecida, entretanto uma considerável proporção de carcinomas epidermóides ocorre em não-fumantes e não-etilistas, indicando a presença de outros fatores de risco (ANAYA-SAAVEDRA et al., 2008). Alguns estudos de caso-controle tem demonstrado que a infecção oral pelo HPV aumenta o risco de desenvolvimento de câncer oral. Evidências moleculares também suportam o papel desse vírus, particularmente do subtipo 16, na patogênese de carcinoma epidermóide da cabeça e pescoço (GILLISON et al., 2000; D'SOUZA et al., 2007a).

\subsection{Mecanismos de oncogênese}

O papel carcinogênico do HPV de alto grau envolve principalmente duas de suas oncoproteínas: as proteínas E7 e E6. A proteína HPV-E7 é capaz de ligar-se à proteína supressora de tumor pRb, que regula a transição $\mathrm{G} 1 / \mathrm{S}$ do ciclo celular, modificando sua estrutura, resultando numa ativação dos fatores de transcrição E2F, que são liberados da pRb. Esses fatores induzem a transcrição de genes 
importantes no controle da divisão celular, por promover a progressão do ciclo celular, atuando nas fases G1 e S (CAMPISI et al., 2007; HENESSEY; WESTRA; CALIFANO, 2009).

A proteína E6 do HPV também mostra um importante papel na transformação celular, graças à sua capacidade de formar complexo com a proteína p53, responsável pela integridade do genoma celular. Essa oncoproteína produzida pelos HPVs 16 e 18 tem mostrado não só a capacidade de formar este complexo, mas também de degradar a p53, por um caminho dependente da ubiquitina. Suas atividades oncogênicas incluem: imortalização de células primárias, transformação de linhagens celulares estabelecidas, resistência à diferenciação celular, tumorigênese e anulação do ponto de checagem do ciclo celular (CAMPISI et al., 2009; HENESSEY; WESTRA; CALIFANO, 2009).

Evidências sugerem que o gene E5 do HPV 16 também pode induzir transformação de células epiteliais, possivelmente aumentando a transdução de sinal intracelular mediado por fatores de crescimento (OLIVEIRA et al., 2003).

Existe uma associação bem estabelecida entre HPV e carcinoma anogenital, entretanto, a relação do HPV com o carcinoma epidermóide oral ainda não está bem estabelecida (OLIVEIRA et al., 2003; WALBOOMERS et al., 1999). A possível relação do HPV na etiologia das lesões cancerizáveis e no câncer oral foi primeiramente estimada em 1983, quando foram descritas alterações citopáticas de HPV (coilócitos) em cânceres orais idênticas àquelas previamente encontradas em neoplasias intra-epiteliais e carcinomas de colo uterino (SYRJÄNEN et al., 1983). Outros estudos suportaram essa teoria baseados nas seguintes evidências: o bem estabelecido epiteliotropismo do HPV, similaridades morfológicas entre o epitélio 
orofaríngeo e genital, a habilidade do HPV em imortalizar queratinócitos in vitro e o fortemente estabelecido papel etiológico do HPV de alto risco no carcinoma epidermóide cervical (SYRJANEN, 2003).

Os carcinomas epidermóides de cabeça e pescoço causados pela associação entre fumo e álcool mostram-se histológica e geneticamente diferentes dos causados pelo HPV. Essas lesões quando relacionadas ao HPV mostram-se pobremente diferenciadas e não-queratinizadas e apresentam um aspecto basalóide distinto. Esses tumores apresentam, ainda, diferenças a nível genético, mostrando menores quantidades de mutações e perdas cromossômicas que tumores HPV negativos. (HENESSEY; WESTRA; CALIFANO, 2009).

Os avanços no campo da genética e biologia molecular têm contribuído decisivamente para o estudo desses vírus. Evidências moleculares também suportam o papel do HPV, particularmente do subtipo 16, na patogênese de carcinoma epidermóide da cabeça e pescoço (GILLISON et al., 2000). Embora ocorrendo numa menor porcentagem que no carcinoma de colo uterino, transcritos E6/E7 e/ou integração viral foram detectados em carcinomas de cabeça e pescoço, sugerindo que o HPV de alto risco está envolvido na inativação dos genes p53 e Rb. Esse fato justificaria a crescente prevalência de carcinoma de cabeça e pescoço em pessoas jovens (CAMPISI; GIOVANELLI, 2009), com os fatores de risco estabelecidos, como álcool ou fumo, presentes ou não. 


\subsection{Técnicas para identificação do HPV}

Desenvolvida há mais de 50 anos, a citologia oncótica tem sido reconhecida como o exame mais utilizado para identificação de alterações celulares decorrentes de infecção pelo HPV na mucosa cervical. Nas últimas 2 décadas, diversos estudos tem apontado para índices não ideais de sensibilidade da citologia convencional, sendo que alguns estudos relatam sensibilidade de 50 a 60\% (KUMAR et al., 2007, YARANDI et al., 2009).

Recentemente, os sistemas de citologia de base líquida foram desenvolvidos a fim de melhorar a exatidão de resultados da citologia convencional por oferecer preparados com resíduos e artefatos reduzidos que poderiam, eventualmente, conduzir a erros de interpretação diagnóstica.

A citologia em base líquida representa um aperfeiçoamento da citologia convencional, pois apresenta um conjunto de vantagens comparada aos métodos convencionais. Esta técnica permite melhor disposição das células analisadas, propiciando melhor interpretação do quadro, redução da presença de mucos, exsudatos inflamatórios e hemácias. Além dos fatos abordados, a técnica permite divisão da amostra em lâminas adicionais sem a necessidade de nova coleta de material. Para diversas aplicações, como a citopatologia, a citologia em base líquida possibilita detecção mais precisa de lesões, quando comparado com o método clássico, como na coloração tipo Papanicolau, na citologia cervical. Apresenta também menor produção de amostras limitadas ou inadequadas ao diagnóstico (LONGATTO-FILHO et al., 2005). 
A detecção direta dos genomas do HPV e seus transcritos pode ser obtida com procedimentos que incluem imunoistoquímica, imunofluorescência, hibridizações Southern blot, Northern blot, dot blot e in situ, PCR, $\mathrm{CH}$, sequenciamento de DNA, dentre outros (FAKHRY et al., 2006). A sensibilidade e especificidade dos vários métodos de detecção do HPV variam amplamente. Eles são divididos em 3 categorias principais: os de baixa sensibilidade (imunoistoquímica, imunofluorescência e hibridização in situ) por só detectarem o vírus quando presente em mais de 10 cópias do DNA viral por célula; os considerados de moderada sensibilidade (Southern blot, dot blot e hibridização dot reversa), por só detectarem o vírus quando de 1 a 10 cópias do DNA viral estiverem presentes e os de alta sensibilidade (PCR e captura híbrida 2), por detectarem 0 vírus quando menos de 1 cópia do DNA estiver presente (MILLER; JOHNSTONE, 2001). Atualmente, os dois métodos mais amplamente utilizados e que apresentam equivalência em sensibilidade são captura híbrida 2 e PCR com iniciadores genéricos.

Na mucosa oral, como a quantidade de DNA-HPV é significativamente menor que a encontrada em colo uterino, os autores sugerem que métodos de alta sensibilidade e especificidade sejam utilizados para as amostras orais (CAMPISI; GIOVANELLI, 2009).

O exame de $\mathrm{CH}$ é uma técnica de hibridização molecular associada a anticorpos monoclonais que permite a detecção de $1 \mathrm{pg} / \mathrm{ml}$ de DNA-HPV, equivalente a 0,1 cópia de vírus por célula. Considerando-se positivo quando as relações RLU/PCA para vírus do grupo A $(6,11,42,43$ e 44) e/ou RLU/PCB para vírus do grupo $B(16,18,31,33,35,39,45,51,52,56,58,59$ e 68$)$ forem iguais ou maiores que 
1 (um). Esta técnica permite, ainda, identificar se o vírus é de baixo ou alto grau de malignidade.

Söderlund-Strand et al. (2005) realizaram um estudo no qual compararam a CH 2 e a PCR na detecção do HPV em 239 mulheres que possuíam neoplasia intraepitelial cervical. Os autores observaram uma concordância substancial entre os dois testes analisados, e sugerem que são ferramentas confiáveis para a detecção e o seguimento de pacientes que apresentam neoplasia intra-epitelial de colo uterino.

Novaes et al. (2006) avaliaram as divergências de resultados obtidas entre a citologia através da coloração de Papanicolaou e a captura híbrida. Para comparação entre as técnicas, utilizaram a técnica da PCR, e avaliaram a concordância entre os métodos. Os autores concluíram que a captura híbrida representa técnica superior em relação à citologia, apresentando resultados semelhantes aos obtidos com a PCR, argumentando que ambos os métodos são eficazes na detecção de infecções latentes. Segundo Dillner (2001), a captura híbrida apresenta sensibilidade de $93 \%$ e especificidade de $61 \%$.

Em recente estudo, Mayrand et al. (2007) compararam o teste para o DNA do HPV oncogênico, utilizando a técnica da captura híbrida 2, e o de Papanicolaou para identificar neoplasia intra-cervical de alto grau em mulheres com idade entre 30 e 69 anos de idade. Concluíram que o teste de captura híbrida 2 apresenta uma maior sensibilidade para detecção da neoplasia intra-epitelial cervical em relação à técnica de Papanicolaou.

A partir do conhecimento de que a utilização de teste para a detecção do DNA do HPV aumenta a sensibilidade de detecção de neoplasia intra-epitelial cervical de alto grau, Naucler et al. (2007) analisaram se este ganho representa uma avaliação 
desnecessária ou uma proteção contra futuro aparecimento de neoplasia intraepitelial de alto grau ou câncer cervical. Concluíram que a adição de testes para o DNA do HPV ao teste de Papanicolaou em mulheres de 30 anos reduz a incidência de neoplasias intra-epiteliais cervical grau 2 ou 3 ou câncer detectados por avaliações subseqüentes.

Lee et al. (2009) avaliaram a performance de 4 testes para identificação de DNA de HPV: captura híbrida $2(\mathrm{CH})$, linear array (LA), DNA-chip e seqüenciamento de ciclo com o objetivo de avaliar suas capacidades em detectar a presença de DNA de alto risco e lesões cervicais associadas. Foram incluídas 76 mulheres com citologia cervical anormal. Concluíram que o LA foi mais sensível na detecção de infecção por HPV e apresenta-se como uma ferramenta importante na identificação dos genótipos de HPV.

Além do comprovado papel do HPV na etiologia do câncer de colo de útero, vários estudos sugerem um papel importante desse vírus no desenvolvimento de câncer de orofaringe (FURRER et al., 2006; GILLISON; LOWY, 2004; OSTWALD et al., 2003;).

A coleta do material a ser analisado para a pesquisa do vírus pode ser realizada através de biópsia ou de células superficiais da mucosa. Quint et al. (2001) observaram que a análise comparativa entre esfregaço cervical e de espécimes de biópsia não mostraram diferença significante na freqüência de detecção do DNA do HPV, porém, o esfregaço cervical mostrou informações mais precisas relacionadas ao espectro dos genótipos de HPV presentes no colo uterino.

Além disso, as células superficiais da mucosa oral podem ser obtidas a partir de bochechos ou raspados. Estudando formas de coleta de material oral, Furrer et 
al. (2006) compararam a realização de biópsia e esfregaço para a obtenção do material a ser analisado para detecção do DNA do HPV, utilizando a PCR. Observaram que o DNA viral é mais facilmente detectado em esfregaços orais que em biópsias, possivelmente devido ao fato que a presença do HPV no epitélio aumenta progressivamente da camada basal $(5,8 \%)$ até as camadas superficiais $(100 \%)$.

Ainda em ser tratando de material de biópsia, Miller e White (1996) revisaram a literatura com relação à presença de HPV em amostras de carcinoma epidermóide detectadas por PCR e observaram que o DNA do HPV foi encontrado mais frequentemente em amostras congeladas $(51,6 \%)$ em relação a amostras parafinizadas. Segundo Simonato et al. (2008), a maior razão para a falha de detecção do HPV em tecidos parafinados é a fragmentação do ácido nucléico que pode ocorrer devido à fixação, parafinização e desparafinização.

\subsection{Prevalência do HPV e fatores de risco associados}

A prevalência do HPV na boca e no colo uterino apresenta números discordantes na literatura dependo da população estudada, do método utilizado para identificação do vírus e da forma da coleta das células, dentre outros.

Estudos epidemiológicos e de biologia molecular têm verificado a alta frequência de infecção pelo HPV, afetando um grande número de pacientes assintomáticos (GIRALDO et al., 2006). Bauer et al. (1991) encontraram uma 
prevalência de HPV genital na população feminina dos Estados Unidos variando entre 30 e $50 \%$.

A partir da constatação de que o HPV pode infectar mucosas de região extragenital, estudos populacionais começaram a ser realizados no intuito de se observar a sua prevalência na boca. Porém, a maioria dos estudos inclui pacientes com papilomas e outras neoplasias orais, sendo restritos os estudos com pacientes sem lesão aparente.

Karlsson et al. (1995) realizaram um estudo populacional para determinar a prevalência do HPV na mucosa genital de mulheres suecas e identificar os possíveis fatores de risco para a infecção. Encontraram uma prevalência de infecção pelo HPV em $22 \%$ das mulheres sexualmente ativas e em $4 \%$ das mulheres que nunca mantiveram relação sexual. A análise de regressão logística mostrou que o número de parceiros sexuais em toda a vida foi o único fator de risco independente relacionado com a infecção.

Giraldo et al. (1996) utilizando exame citológico com coloração de Papanicolaou, observaram presença do vírus HPV no epitélio da orofaringe em $6 \%$ de mulheres que apresentavam lesão causada pelo vírus na região genital. Os autores alertaram para a possibilidade de reservatório de HPV em sítio fora da região genital, que poderia servir como foco de reinfecção.

Alguns estudos mostram que os pacientes HIV-positivos apresentam um risco aumentado para a infecção anogenital e oral pelo HPV e, consequentemente, para o desenvolvimento de neoplasias intra-epiteliais associadas ao vírus e ao câncer. Outros fatores de risco relacionados são variados e incluem: níveis de CD4 baixos e número elevado de parceiros sexuais (COUTLÉE et al., 1997; JAMIESON et al., 
2002; KARLSSON et al., 1995; KREIMER et al., 2004; MINKOFF et al., 1999; PALEFSKY, 2006).

Coutlée et al. (1997) estudaram a prevalência e os fatores de risco para a infecção oral pelo HPV estudando indivíduos HIV positivos $(n=178)$ e HIV negativos $(n=109)$ através da PCR. Observaram que 11\% dos pacientes apresentaram infecção oral pelo vírus. Os autores concluíram que os pacientes HIV positivos, homossexuais, que não usavam preservativo e que apresentam outras doenças sexualmente transmissíveis como sífilis, gonorréia, clamídia e herpes genital, exibiam maior prevalência de HPV.

Badaracco et al. (1998) pesquisaram a prevalência da infecção pelo HPV e a ocorrência de co-infecção na cavidade oral e no trato genital de 29 mulheres através da PCR. Observaram prevalência de HPV na cavidade oral de $37,9 \%$ e no trato genital de $34,5 \%$. A presença de HPV em ambos trato genital e cavidade oral foi observada em $17,24 \%$ dos pacientes sendo que $60 \%$ apresentaram concordância entre os subtipos.

Minkoff et al. (1999) realizaram um estudo com o objetivo de determinar a prevalência, incidência e preditores de desordens ginecológicas em mulheres portadoras do vírus HIV. Para isso, examinaram 292 mulheres HIV positivas e 681 HIV negativas e concluíram que mulheres portadoras do vírus HIV são predispostas a apresentar candidíase vulvovaginal, esfregaços cervicais corados com Papanicolaou anormais, amenorréia e infecção por HPV e CMV.

Palefsky et al. (1999) desenvolveram pesquisa com o objetivo de avaliar a prevalência e os fatores de risco associados à infecção cervical pelo HPV em mulheres soropositivas $(n=1778)$ e soronegativas (500) para o HIV. Observaram 
uma maior prevalência de infecção pelo HPV em mulheres soropositivas (63\%) em relação às soronegativas para HIV (30\%). Os fatores de risco associados a ambos os grupos foram: idade precoce (<30 anos), ausência de gravidez prévia, história de verruga ou lesão genital e cor negra. Os fatores de risco associados apenas às mulheres HIV+ foram: baixa renda, fumo e níveis de CD4 $<200$ céls $/ \mathrm{mm}^{3}$ e carga viral > 20.000 cópias $/ \mathrm{ml}$.

Jamieson et al. (2002) avaliaram a prevalência de infecção cervical pelo HPV através da PCR e analisaram a probabilidade de expressão do HPV com desenvolvimento de anormalidades citológicas em mulheres HIV+ (767) ou com comportamento de risco para DST (390). Encontraram uma maior prevalência de infecção pelo HPV genital em mulheres soropositivas (64\%) em relação às soronegativas (27\%), porém concluíram que os subtipos do HPV encontrados em ambos os grupos foram similares. Os autores concluíram que os pacientes soropositivos para o HIV podem apresentar risco aumentado para o desenvolvimento de displasia cervical em mulheres infectadas pelo HPV.

Levi et al. (2002a) estudaram a prevalência e genótipos de HPV na mucosa cervical de 208 mulheres soropositivas para o HIV através de PCR SPF10. Quase a totalidade das mulheres (98\%) apresentaram positividade para o DNA de HPV, sendo observada uma alta prevalência de genótipos múltiplos (78,9\%). O HPV 6 foi o genótipo mais comum, seguido pelo 51, 11, 18 e 16. A citologia exibiu resultado alterado para apenas $13,4 \%$ das pacientes. Os autores não observaram associação entre o número de genótipos de HPV detectados e a classificação citológica, a carga viral do HIV e a contagem de CD4. Concluíram, ainda, que uma proporção muito alta 
de mulheres soropositivas para o HIV no Brasil são infectadas pelo HPV e geralmente carregam múltiplos genótipos.

Levi et al. (2002b) realizaram estudo com o objetivo de determinar a prevalência de DNA-HPV na mucosa cervical, a presença de neoplasia intra-epitelial e contagem de células CD4 e carga viral em 265 mulheres soropositivas para o HIV através da $\mathrm{CH} 2$. Foi observada uma prevalência de DNA de HPV de 64,5\%, sendo que exames citológicos anormais foram identificados em 19\% das pacientes. Os autores concluíram que a contagem de CD4<100 céls $/ \mathrm{ml}$ é fator de risco para desenvolvimento de infecção pelo HPV e neoplasia intracervical.

Levi et al. (2004) avaliaram a prevalência e identificaram os subtipos de HPV na mucosa cervical de mulheres infectadas pelo HIV $(n=255)$ e em grupo de mulheres HIV-, com diagnóstico de condiloma ou neoplasia intra-epitelial, através da PCR. Observaram presença de DNA de HPV em $87 \%$ das pacientes HIV+, sendo que $45 \%$ apresentaram mais de 2 subtipos de HPV. Todas as mulheres HIVmostraram positividade para o HPV, sendo que $41,66 \%$ apresentaram mais de 2 subtipos de HPV. Concluíram que mulheres HIV+ apresentaram maior chance de múltiplos tipos de HPV, porém a infecção concomitante com 3 ou mais tipos de HPV não conferiu risco adicional para o desenvolvimento de displasia cervical em comparação com infecção dupla ou simples.

Rama et al. (2008) analisaram a prevalência da infecção genital por HPV de alto risco segundo idade e seus fatores de risco em 2.300 mulheres submetidas a rastreamento para o câncer cervical, através da $\mathrm{CH} 2$. Observaram presença de DNA-HPV em $17,8 \%$ das pacientes. Os fatores de risco associados a infecção pelo HPV foram: maior número de parceiros sexuais durante a vida e idade (inferior a 25 
anos e superior a 55 anos). A presença do DNA-HPV foi observada em $14,3 \%$ das citologias normais, $77,8 \%$ das lesões escamosas de alto grau e nos 2 casos de carcinoma.

Com relação aos subtipos de HPV mais prevalentes na mucosa oral, os autores são unânimes em afirmar que os genótipos 16 e 18 são os mais freqüentemente encontrados (FURRER et al., 2006; LUO; ROAN; LIU, 2007; OSTWALD et al., 2003; PRAETORIUS, 1997; SYRJÄNEN, 2003;). Um estudo de meta-análise concluiu que o subtipo de HPV mais envolvido no carcinoma epidermóide é o 16, seguido por 18,45,31 e 33. Em adenocarcinomas, o mais comum é o HPV 18, seguido pelo 16 e 45 (CLIFFORD et al., 2003).

Miller e Johnstone (2001), em uma meta-análise, encontraram que o índice de HPV na mucosa oral normal corresponde a 15\%, sendo o subtipo 16 o mais prevalente. Os autores concluíram que a possibilidade de detecção de HPV é duas a três vezes maior em lesões cancerizáveis e quatro a sete vezes maior em carcinomas orais em relação à mucosa oral normal.

Hormia et al. (2005) avaliaram biópsias de indivíduos com doença periodontal clinicamente diagnosticada com a finalidade de se determinar se a bolsa periodontal pode representar um reservatório para o HPV. Foram realizadas a PCR e a hibridização in situ. Observaram presença de DNA-HPV em 26\% das amostras, sendo observado um baixo número de cópias. Os autores concluíram que a bolsa periodontal pode representar um reservatório de infecção latente pelo HPV.

Furrer et al. (2006) pesquisaram a prevalência de HPV em lesões orais cancerizáveis e malignas através de biópsia e esfregaços superficiais pela técnica da PCR. Encontraram que $100 \%$ dos pacientes que apresentavam lesões avaliadas 
clinicamente como malignas ou cancerizáveis foram HPV-positivos, sendo o subtipo HPV 16 o mais freqüente.

Ostwald et al. (2003) avaliaram a presença de HPV em lesões orais de carcinomas epidermóides, leucoplasias, queilite actínica e líquen plano de 267 pacientes através da técnica da PCR. Observaram presença do vírus em $43,2 \%$ dos carcinomas orais, sendo os subtipos 16 e 18 mais freqüentemente associados a essas lesões. Quanto às leucoplasias, observaram presença do vírus em $22,2 \%$ dos casos, sendo o subtipo 16 mais freqüentemente associado, seguido pelos 6 e $11 . \mathrm{Na}$ queilite actínica, notou-se presença de HPV em $25 \%$ dos casos, com prevalência do subtipo 16 e no líquen plano, em 15,4\%, com maior frequência do subtipo 18 . Os resultados indicaram um sucessivo aumento na deteç̧ão de HPV 16 e 18 em líquen plano para leucoplasia e queilite actínica e destas para carcinoma epidermóide, sugerindo uma associação da infecção pelo HPV de alto risco (16 e 18) e a carcinogênese oral.

Cañadas et al. (2004) estudaram a prevalência e concordância entre os subtipos de HPV em 5 localizações diferentes de 188 mulheres profissionais do sexo através da PCR. Foi observada presença de HPV em 27,8\% das amostras cervicais, $26,1 \%$ das amostras de vagina, $22,9 \%$ das amostras de vulva, $15 \%$ das amostras anais e $7,9 \%$ das amostras orais. Os subtipos de HPV 16 e 18 foram mais prevalentes na mucosa genital, enquanto que o HPV 6 foi mais freqüente na mucosa bucal. Os autores concluíram que existe relação entre a infecção pelo HPV e subtipos na região genital, mas não foi observada relação entre as infecções oral e genital. Além disso, observaram que a idade foi fator de risco para a presença de HPV na região anogenital. 
Kreimer et al. (2004) investigaram a prevalência de infecção pelo HPV, a distribuição com relação ao subtipo do vírus na mucosa oral de 396 indivíduos soronegativos para o vírus HIV e 190 portadores do vírus através da PCR e determinaram os fatores de risco para a infecção oral pelo HPV. Os autores observaram uma maior prevalência de infecção por HPV de alto risco na boca de pacientes HIV-positivo. Além disso, observaram que o HPV-16 foi o subtipo mais prevalente na cavidade oral. Os fatores de risco relacionados foram: sexo masculino, níveis de CD4 $<200$ células $/ \mathrm{mm}^{3}$ e mais que 1 parceiro sexual durante o último ano.

Cameron et al. (2005) determinaram a prevalência do HPV e o impacto da HAART numa população de 98 pacientes HIV+ através da PCR. Observaram que o HPV foi detectado na mucosa oral de $37 \%$ dos indivíduos estudados, sendo os subtipos de alto risco (16, 55 e 83) mais freqüentes. Com relação ao impacto da HAART na presença de infecção, somente na cor branca a HAART apresentou-se como fator de risco significativo da infecção oral pelo HPV.

Fakhry et al. (2006) estudaram a prevalência e a relação entre as infecções oral e cervical pelo HPV em pacientes HIV+ e HIV- através da PCR. Observaram uma maior prevalência de infecção cervical nos 2 grupos estudados. Foi observada ainda maior prevalência de infecção oral associada à presença de infecção cervical. Nenhuma menção foi feita acerca de presença ou ausência de lesão macroscópica. Os autores concluíram que os reservatórios oral e cervical para o HPV não são totalmente independentes entre si.

Furrer et al. (2006) avaliaram a presença do DNA viral em pacientes que apresentavam lesões potencialmente malignas e malignas, como também da 
mucosa oral normal contralateral, observando que quando o DNA viral era detectado nas lesões, a mucosa normal também continha o vírus, mostrando infecção generalizada da mucosa.

Giraldo et al. (2006) estudaram a freqüência de HPV na cavidade oral de mulheres com $(n=70)$ e sem $(n=70)$ lesões genitais macroscópicas causadas pelo HPV através da técnica da PCR. Observaram presença de DNA do HPV na cavidade oral de 29 mulheres (20,7\%). Os autores não observaram associação entre a presença de HPV na boca e idade, cor de pele, nível educacional, fumo, número de parceiros e prática de sexo oral. Porém, concluíram que o DNA do HPV estava significativamente mais prevalente na cavidade oral de mulheres com lesões genitais que no grupo sem lesões.

Magi et al. (2006) estudaram 64 pacientes (38 do sexo masculino e 26 do sexo feminino) atendidos em um ambulatório geral de Proctologia com objetivo de verificar a prevalência de HPV anal, oral ou genital, por meio da $\mathrm{CH} 2$. Os resultados mostraram que $6,25 \%$ dos pacientes apresentavam presença de HPV na boca, 4,68\% no ânus, $1,56 \%$ no pênis e 4,68\% na vulva. Apenas 1 paciente apresentou 2 sítios acometidos (ânus e vulva).

Para Rose et al. (2006), a incidência da infecção assintomática pelo HPV em boca varia entre 0 e $80 \%$, sendo os valores mais altos encontrados em populações mais jovens. Este fato leva os autores a concluir que a maior prevalência de HPV está diretamente relacionada à idade dos grupos analisados.

D’Souza et al. (2007b) estudaram 136 mulheres HIV+ e 63 HIV- , em 0 e 6 meses, na tentativa de entender a história natural da infecção pelo HPV oral. Encontraram uma maior prevalência de infecção pelo HPV oral e cervical em 
mulheres $\mathrm{HIV}+$. Os fatores de risco relacionados à persistência da infecção oral diferiram dos relacionados à infecção cervical e foram: fumo, idade $<44$ anos, CD4<500 céls $/ \mathrm{mm}^{3}$ e uso de HAART.

Num estudo de caso controle, D’Souza et al. (2007a) avaliaram a infecção pelo HPV em 100 pacientes com carcinoma de orofaringe, comparando com 200 pacientes sem lesão através da hibridização in situ com amplificação de sinal. Observaram significativa associação entre o câncer orofaríngeo e a infecção oral pelo HPV 16, sendo que $72 \%$ dos tumores foram positivos para esse vírus. Os autores encontraram uma relação positiva entre a prática de sexo oral e o desenvolvimento de câncer de orofaringe.

Luo; Roan; Liu (2007) determinaram a freqüência e o tipo de HPV em carcinomas epidermóides e mucosa bucal normal. Observaram que, de uma forma geral, a prevalência de HPV no carcinoma epidermóide não foi maior que na mucosa bucal normal havendo, porém, uma maior prevalência de HPV de alto-risco oncogênico no carcinoma epidermóide.

Xavier et al. (2007) realizaram um estudo com o objetivo de determinar a freqüência de aparecimento de HPV na cavidade oral de homens com HPV anogenital. Foram selecionados 10 pacientes com HPV anogenital confirmado por biologia molecular, nos quais foi realizado exame da cavidade oral por raspado (na ausência de lesão oral) ou por biópsia (com lesão oral). Os resultados mostraram que nenhum paciente apresentou lesão na cavidade oral e também nenhuma amostra de cavidade oral foi positiva para HPV.

Adamopoulou et al. (2008), utilizando PCR com iniciador consensual, observaram uma significativa maior prevalência de HPV na mucosa oral de 
pacientes HIV+ $(35,3 \%)$ em relação a pacientes HIV- que apresentavam carcinoma epidermóide oral (10,3\%).

Anaya-Saavedra et al. (2008) realizaram um estudo de caso controle com o objetivo de determinar a associação entre a presença de HPV de alto risco e o desenvolvimento de carcinoma epidermóide oral, assim como avaliar os fatores de risco associados. Utilizando a PCR, os autores observaram presença de HPV em 43\% dos carcinomas epidermóides e em 9,7\% dos pacientes do grupo controle. Os autores concluíram que existe uma forte relação entre a presença de HPV de alto risco na boca e o desenvolvimento de carcinoma epidermóide. Relataram, ainda, que os subtipos 16 e 18 foram os mais prevalentes e que hábitos sexuais como coitarca precoce e múltiplos parceiros sexuais na vida foram fatores de risco à infecção oral pelo HPV.

Andrews; Seaman; Webster-Cyriaque (2008) realizaram pesquisa com o objetivo de determinar se a infecção pelo HPV de alto risco apresenta associação com o desenvolvimento de carcinoma epidermóide em não-fumantes e não-etilistas. Incluíram 40 pacientes, sendo que 18 apresentavam carcinoma na cavidade oral ou orofaringe (grupo de estudo) e 22 não apresentavam lesão maligna, sendo que 10 tinham história de câncer. A identificação do DNA do HPV foi realizada através da PCR em tempo real. Observaram que os carcinomas apresentaram 6.1 vezes mais HPV de alto risco que os controles, sendo que $30 \%$ dos pacientes que apresentavam história prévia de câncer apresentaram HPV de alto risco. Os autores sugeriram que o HPV apresenta papel importante na transformação do epitélio oral.

Gillison et al., 2008 realizaram um estudo de caso-controle com 240 indivíduos com câncer de orofaringe. Observaram que 92 apresentavam positividade 
para o HPV 16. Além disso, observaram que o risco para desenvolvimento de carcinoma de cabeça e pescoço aumenta de acordo com o número de parceiros para sexo oral assim como uso de maconha.

Segundo Kreimer et al. (2005), o DNA genômico do HPV é detectado em aproximadamente $26 \%$ de todos os carcinomas epidermóides da cabeça e pescoço. Simonato et al. (2008) investigaram a prevalência de HPV no carcinoma epidermóide de assoalho de boca através de PCR. O DNA do HPV foi detectado em 17,2\% dos espécimes. A baixa prevalência de HPV nesses tumores sugere que esse vírus não tem um papel essencial no desenvolvimento de carcinoma epidermóide de assoalho bucal.

González-Rosa et al. (2008) avaliaram a presença de DNA-HPV de alto risco na mucosa oral sem lesão aparente de 77 indivíduos utilizando-se a técnica de $\mathrm{CH} 2$. Observaram uma prevalência de HPV de alto risco em apenas 1 paciente $(5,71 \%)$.

Richter et al. (2008) avaliaram a prevalência e os subtipos de HPV nas mucosas oral e cervical sem lesões aparentes de mulheres HIV+ com contagem de CD4+ menor que 300 células por ml através do linear array. Observaram presença de HPV oral em $20 \%$ das pacientes, sendo que $96,7 \%$ apresentaram HPV no colo uterino. Os autores observaram que as mulheres $\mathrm{HIV}+$ com contagem de células CD4 menor que 300 células por $\mathrm{ml}$ apresentam um risco significante para a presença de HPV cervical com vários subtipos virais. Notaram, ainda, uma baixa prevalência de HPV oral nessas pacientes, mas subtipos de alto risco foram encontrados na boca. Concluíram que existe limitada correlação entre os subtipos de HPV na boca e no colo uterino. 
Syrjänen et al. (2008) realizaram um estudo de caso-controle no intuito de avaliar o papel do uso regular de drogas como um preditor independente de infecção por HPV de alto risco e de neoplasia intraepitelial cervical. Concluíram que o vício por drogas não é um fator independente para a infecção pelo HPV nem para o desenvolvimento de neoplasias intra-cervicais, mas a prevalência aumentada de HPV de alto-risco nessa população pode ser explicada pelo comportamento sexual de alto risco e pelo hábito de fumar dessas mulheres.

D’Souza et al. (2009) realizaram coleta de amostras orais e aplicação de questionários com o objetivo de se estudar a presença de HPV na população normal e avaliar os possíveis fatores de risco relacionados. Foram estudados 2 grupos de pacientes: pacientes atendidos consecutivamente no serviço de Otorrinolaringologia de um Hospital (Grupo 1) e estudantes de uma Universidade com idade superior a 17 anos (Grupo 2). Foi observada presença de DNA-HPV em 2,9\% dos pacientes do grupo 1 e 4,8\% dos pacientes do grupo 2. Os fatores de risco associados à infecção pelo HPV foram: fumo, sexo oral e beijo com boca aberta. Os autores indicam que beijo com boca aberta pode ser uma forma de transmissão de HPV, já que foi observada presença de DNA-HPV na cavidade oral de pessoas que nunca realizaram sexo oral nem vaginal.

Grinsztejn et al. (2009) pesquisaram os fatores associados a maior prevalência de HPV na região cervical em 634 pacientes HIV+ através da $\mathrm{CH} 2 \mathrm{e}$ PCR. Os resultados mostraram que $48 \%$ das mulheres mostraram infecção pelo HPV, sendo que destas, 94\% foram infectadas com HPV de alto-risco. Os fatores independentemente associados com a infecção pelo HPV foram: idade precoce (menor que 30 anos), uso de drogas presente ou passado, história de HPV auto- 
referida, uso de camisinha na última relação sexual e contagem de células T CD4 < 100 céls $/ \mathrm{mm}^{3}$.

Sikora, Morris e Sturgis (2009) testaram a hipótese da associação entre cânceres anogenitais e de orofaringe associados ao HPV. O estudo incluiu 47.308 homens com idade superior a 20 anos e concluiu que a presença de carcinoma em orofaringe apresenta relação com desenvolvimento de câncer na região anogenital e vice-versa.

\subsection{Transmissão do HPV para a boca}

O mecanismo de transmissão do HPV para a cavidade oral permanece ainda parcialmente desconhecido, sendo que algumas teorias incluem: transmissão perinatal, auto-inoculação e/ou prática de sexo oral em parceiros HPV+ (GIRALDO et al., 2006; CAMPISI; GIOVANELLI, 2009). A possibilidade de auto-inoculação em mulheres com HPV genital é ainda um assunto bastante debatido, requerendo que mais estudos sejam realizados (GIRALDO et al., 2006). O sexo oral tem sido considerado o modo principal de transmissão de HPV para a cavidade oral (CAMPISI; GIOVANELLI, 2009).

A freqüência de sexo oral na população pode ser muito alta, atingindo um nível de $90 \%$ em algumas populações. Ainda não foi constatada relação direta entre sexo oral e câncer da orofaringe (RAJKUMAR et al., 2003), porém um aumentado risco de câncer orofaríngeo têm sido observado em homens que praticam sexo oral. 
A relação entre lesões genitais de HPV e prática de sexo oral e a presença de vírus na cavidade orofaríngea permanece incerta.

Muitos aspectos concernentes à inter-relação entre as infecções oral e genital permanecem ainda desconhecidos, especialmente em pacientes HIV positivas. Desta forma, são necessários mais estudos que possibilitem avaliar a prevalência dessa infecção na boca e na mucosa de colo uterino, pesquisando-se os subtipos do HPV mais comuns, avaliando-se as possíveis formas de transmissão e outras variáveis clínicas de pacientes HIV positivas e negativas. 


\section{PROPOSIÇÃO}

O presente estudo teve como objetivo principal avaliar a correlação entre as infecções pelo HPV na mucosa oral e no colo uterino em mulheres com sorologia positiva e negativa para o HIV, atendidas em um centro especializado para tratamento de doenças sexualmente transmissíveis.

Como objetivo secundário, pretendeu-se identificar as variáveis clínicas, demográficas e laboratoriais associadas à infecção oral pelo HPV. 


\section{MATERIAIS E MÉTODOS}

\subsection{Tipo de estudo}

Trata-se de um estudo observacional transversal.

\subsection{Aspectos éticos}

Este estudo foi iniciado após a aprovação dos Comitês de Ética em Pesquisa da Faculdade de Odontologia da Universidade de São Paulo (Protocolo 177/07, Anexo A) e do Centro de Referência e Treinamento em DST-AIDS (Parecer 055/08).

Todas as pacientes foram informadas previamente a respeito dos princípios e objetivos do protocolo. Cada paciente ou responsável legal forneceu o consentimento por escrito antes da inclusão no estudo, obedecendo à resolução 196/96 do Conselho Nacional de Saúde, que regulamenta diretrizes e normas de pesquisa envolvendo seres humanos (Anexo B). 
4.3 Casuística e delineamento do estudo

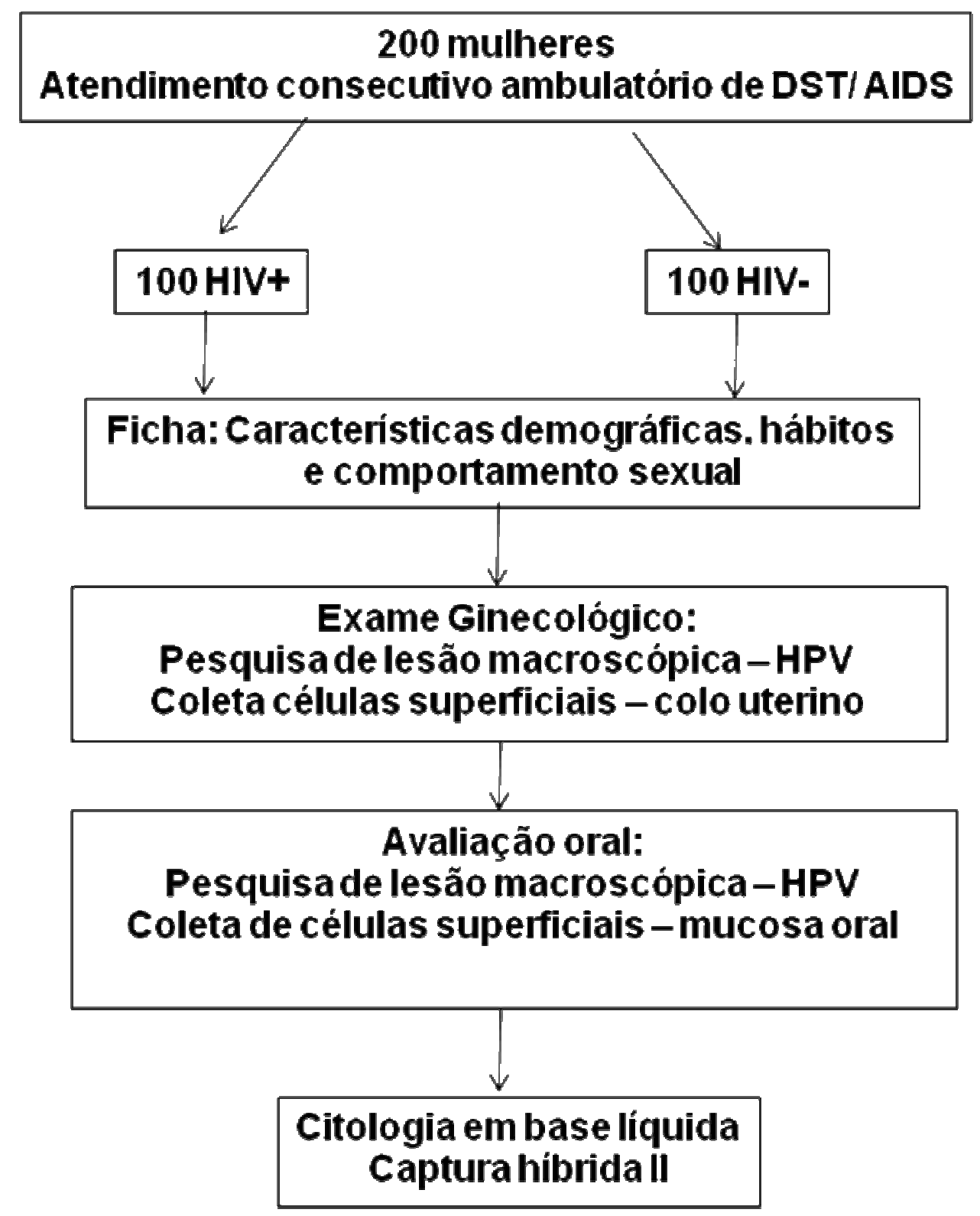

Figura 4.1 - Modelo representativo do delineamento da pesquisa

Foram selecionadas, de forma consecutiva, 200 pacientes do gênero feminino, em atendimento ambulatorial no Centro de Referência e Treinamento em DST/AIDS, no período entre 28 de abril de 2008 e 04 de maio de 2009. 
As pacientes incluídas, neste estudo, apresentavam elevada vulnerabilidade às DST, incluindo profissionais do sexo, pacientes com história ou presença de DST, usuárias de drogas ilícitas, parceiras sexuais de pacientes com DST e mulheres com sorologia positiva para HIV.

As pacientes selecionadas foram distribuídas em 2 grupos de acordo com a soropositividade para o HIV. O grupo 1 foi composto por 100 pacientes com sorologia positiva [G1 (HIV+)] e o grupo 2 por 100 pacientes com sorologia negativa para o HIV [G2 (HIV-)] que aceitaram participar do estudo e assinaram o Termo de Consentimento Livre e Esclarecido (Anexo B). Foram consideradas não elegíveis para o estudo pacientes gestantes devido à contra-indicação para a realização da metodologia empregada.

Os dados demográficos, as características sobre o comportamento sexual e os hábitos das pacientes foram incluídos em uma ficha especialmente elaborada para o estudo (Anexo C), que foi elaborada com base em pesquisas na literatura e adaptada aos objetivos do estudo. As informações foram obtidas por meio do autopreenchimento de ficha contendo questionamentos sobre idade, auto-avaliação da cor da pele, nível de escolaridade, consumo de bebida alcoólica, tabagismo, uso de drogas injetáveis ilícitas, história passada ou presente de DST e hábitos sexuais. Essas fichas foram identificadas apenas pelo número de inclusão da paciente com o objetivo de preservar sua privacidade.

Para as pacientes do G1 (HIV+), foram coletados dos prontuários dados clínico-laboratoriais adicionais, tais como provável meio de contaminação pelo HIV, terapia antiretroviral (TAR) em uso, contagem de células CD4 (céls $/ \mathrm{mm}^{3}$ ) e da carga viral (CV) do HIV (cópias/ml) (Anexo D). A contagem das células CD4 e da CV 
consideradas neste estudo foram as realizadas até 3 meses antes da data da inclusão e coleta.

Este estudo envolveu, além do preenchimento da ficha sobre dados demográficos, hábitos e comportamento sexual, exame ginecológico e da cavidade oral acompanhado de coleta de células da mucosa oral e do colo uterino, para realização de citologia em base líquida e teste para detecção de DNA-HPV nas amostras coletadas.

\subsection{Exame clínico e coleta de células da mucosa oral}

O exame clínico da mucosa oral foi realizado sempre pela mesma cirurgiã dentista, autora do estudo, que observou a presença ou ausência de lesão macroscópica na cavidade oral, sugestiva de infecção pelo HPV.

A coleta das células superficiais da mucosa oral foi realizada por meio de raspagem da mucosa jugal com utilização de escova estéril, com cerdas macias e dispostas em forma cônica (kit Universal Collection Medium, UCM®, Digene Corporation, São Paulo-SP, Brasil). Após a coleta do material, a escova era inserida em tubo contendo meio para conservação do material composto por N-butanol, polietilenoglicol, ácido acético glacial, azida sódica, EDTA qsq e água deionizada. A haste da escova era quebrada, o tubo fechado, identificado e agitado durante 30 segundos para homogeneização do material. 


\subsection{Exame ginecológico e coleta das células cervicais}

As consultas ginecológicas foram conduzidas por duas médicas ginecologistas do corpo clínico do CRT DST-AIDS e incluíram o exame macroscópico da região genital a fim de se observar a presença ou ausência de lesão macroscópica sugestiva de infecção pelo HPV, sendo posteriormente colhido o material destinado ao exame. A coleta das células da mucosa de colo uterino (endocérvice e ectocérvice) era realizada com utilização de escova estéril (kit UCM®, Digene Corporation, São Paulo-SP, Brasil) semelhante à utilizada para a coleta oral. A escova era introduzida no canal cervical entre 1 a $1,5 \mathrm{~cm}$ até que as cerdas maiores tocassem a região ectocervical, sendo realizado movimento de rotação sobre o próprio eixo no sentido horário por 5 vezes. Em seguida, era realizada a coleta do material ectocervical. A escova era inserida no tubo contendo meio para conservação do material ( $\mathrm{N}$-butanol, polietilenoglicol, ácido acético glacial, azida sódica, EDTA qsq e água deionizada), a haste da escova era quebrada e o tubo fechado e agitado durante 30 segundos para homogeneização do material.

\subsection{Armazenamento e transporte do material coletado}

Todas as amostras coletadas foram armazenadas e transportadas em tubos do kit UCM® (Digene Corporation, São Paulo-SP, Brasil) que contêm $1 \mathrm{ml}$ de meio 
líquido de transporte e preservação celular. Em seguida foram armazenadas em refrigerador com temperatura controlada, entre 2 a $8^{\circ} \mathrm{C}$, até o momento das análises.

\subsection{Citologia em base líquida}

4.7.1 preparo das lâminas citológicas

Para a realização da citologia em base líquida, foi utilizado o sistema DNA citoliq ${ }^{\circledR}$ (Digene Corporation, São Paulo-SP, Brasil). Inicialmente, os tubos com as amostras coletadas foram homogeneizados individualmente em agitador vórtex (VM 3000C, Vixar, São Paulo-SP) a 3000 rpm por 15 segundos. Essa etapa teve como objetivo desprender as células contidas nas cerdas das escovas coletoras e, em seguida, $200 \mu \mathrm{l}$ da suspensão eram pipetados e dispensados uniformemente sobre uma membrana de policarbonato, utilizando-se um equipamento específico para essa finalidade (Prepgene® - Digene Corporation, São Paulo-SP, Brasil) (Figura 4.2). Nesta fase do estudo, foram realizadas a fixação e a compressão das lâminas sobre as membranas por 10 segundos. Posteriormente, as lâminas foram fixadas em álcool absoluto por no mínimo 2 horas e seguiram para coloração de Papanicolaou modificada. 

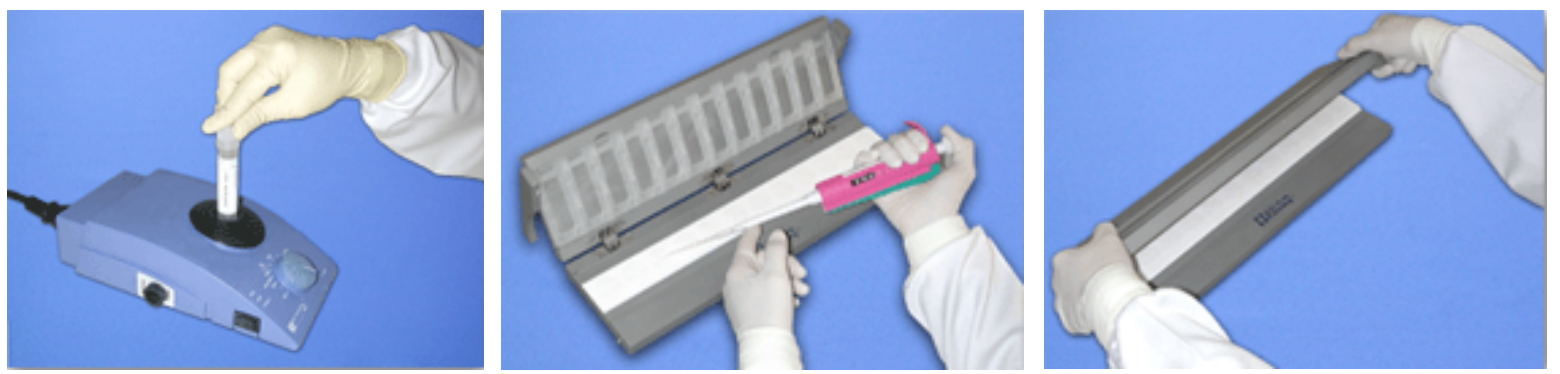

Figura 4.2 - Método de realização da citologia em base líquida

4.7.2 técnica para coloração de Papanicolaou modificada

As lâminas, após lavadas em água corrente por 10 minutos, passavam por 10 banhos em água destilada e eram imersas em solução de Hematoxilina de Harris (5g hematoxilina, $50 \mathrm{ml}$ álcool etílico absoluto, $100 \mathrm{~g}$ alúmen de potássio, 2,5g de mercúrio vermelho) por 1 minuto e 45 segundos. Após o processamento referido, as lâminas sofriam nova lavagem em água corrente (10 minutos) e água destilada e eram imersas em álcool etílico absoluto (10 banhos). Posteriormente, eram imersas em solução de Orange $\mathrm{G}(5 \mathrm{~g}$ Orange $\mathrm{G}, 50 \mathrm{ml}$ água destilada, $0,15 \mathrm{~g}$ ácido fosfotúngstico, $950 \mathrm{ml}$ de álcool etílico absoluto) por 1 minuto e 20 segundos. As lâminas passavam novamente por banhos em álcool etílico absoluto (10 banhos) e eram coradas em solução de eosina-amarela $(5 \mathrm{~g}$ de eosina $\mathrm{Y}, 50 \mathrm{ml}$ de água destilada, 950ml de álcool etílico absoluto) por 30 segundos e lavadas em álcool etílico absoluto (10 banhos). Em seguida, as lâminas eram colocadas sobre bandeja onde permaneciam por no mínimo 30 minutos, para secagem.

Em capela de segurança química, foram distribuídas lamínulas de vidro sobre papel de filtro nas quais foram pingadas de 1 a 2 gotas de resina Permount (Fisher 
Scientific, Fair Lawn, NJ/USA), sendo as lâminas com os esfregaços dispostas suavemente sobre as lamínulas e, quando observado excesso, utilizavam-se compressas de gaze para remoção da resina.

A avaliação das lâminas citológicas foi realizada por uma única especialista do Laboratório da Divisão de Patologia do Instituto Adolfo Lutz de São Paulo, sendo utilizada a classificação de Bethesda (2001) (SOLOMON et al., 2002). Segundo essa terminologia, as células epiteliais podem ser categorizadas em: (1) dentro dos limites da normalidade, (2) inflamação, (3) células atípicas de significado indeterminado possivelmente não-neoplásicas (CASI), (4) células atípicas de significado indeterminado - não sendo possível afastar lesão de alto grau (CASI-D), (5) lesão intra-epitelial escamosa de baixo grau - compreendendo efeito citopático pelo HPV e neoplasia intra-epitelial cervical grau I (LIBG), (6) lesão intra-epitelial escamosa de alto grau - compreendendo neoplasias intra-epiteliais graus II e III (LIAG), (7) lesão intra-epitelial de alto grau - não podendo excluir micro-invasão (LIAG-microinvasão) e (7) carcinoma epidermóide invasor (Ca).

\subsection{Técnica de captura híbrida 2}

Para a identificação do DNA-HPV, foi realizado o teste de $\mathrm{CH} 2$, em que cada amostra foi submetida a duas reações distintas utilizando-se sondas para identificação de vírus de alto risco $(16,18,31,33,35,39,45,51,52,56,58,59$ e 68$)$ e de baixo risco $(6,11,42,43,44)$. 
Para a execução da $\mathrm{CH}$ 2, foi utilizado um kit (Digene Corporation, São PauloSP, Brasil) contendo todos os reagentes necessários para a realização do teste, o qual consiste em seis fases.

Inicialmente, foi realizada a fase de desnaturação, em que $500 \mu l$ de reagente de desnaturação foram pipetados no tubo com amostra e homogeneizados em agitador vórtex (VM 3000C, Vixar, São Paulo-SP). As amostras tornaram-se púrpuras e, nesse momento, seguiram para incubação a $65^{\circ} \mathrm{C}$ por 45 minutos.

$\mathrm{Na}$ fase de hibridização, $25 \mu \mathrm{l}$ de sonda (preparada de acordo com as recomendações do fabricante) e $75 \mu$ l de amostra foram colocadas em microplaca e homogeneizadas no Rotary-Shaker® (Digene Corporation, São Paulo-SP, Brasil) a $1.100 \mathrm{rpm}$ por 2 minutos. Em seguida, o material foi incubado a $65^{\circ} \mathrm{C}$ por 60 minutos. Nessa fase, os espécimes contendo DNA do vírus hibridizam-se com o RNA do coquetel de sondas.

$\mathrm{Na}$ fase de captura dos híbridos, todo o material foi transferido para a microplaca e levado ao aparelho Rotary-Shaker®) (Digene Corporation, São PauloSP, Brasil) a 1.100 rpm por 60 minutos a $20-25^{\circ} \mathrm{C}$.

$\mathrm{Na}$ fase de reação com o conjugado, todo o conteúdo da microplaca foi desprezado, sendo adicionados $75 \mu$ l de reagente de detecção 1 em cada micropoço, seguindo para incubação a $20-25^{\circ} \mathrm{C}$ por 30 minutos.

A fase de amplificação de sinais consistiu na adição de $75 \mu$ le reagente de detecção 2 em cada micropoço e na incubação a 20-25C por 15 minutos. E, por fim, a microplaca foi inserida no aparelho de quimioluminescência DML-2000®) (Digene Corporation, São Paulo-SP, Brasil), responsável pela leitura da luz resultante da 
reação, que é proporcional à quantidade de DNA presente na amostra, fornecendo uma medida semi-quantitativa.

Os valores lidos pelo quimioluminômetro foram transmitidos a um microcomputador, dotado de software específico®) (Digene Corporation, São PauloSP, Brasil), com o objetivo de analisar os números recebidos e executar os cálculos de validação do ensaio e a quantificação dos controles positivos, negativos e amostras. As amostras foram classificadas como HPV positiva para alto risco ou como HPV positiva para baixo risco, quando a leitura do quimioluminômetro foi igual ou superior ao valor do controle positivo, ou seja, unidade de luz relativa $\geq 1.0 \mathrm{pg} / \mathrm{ml}$.

\subsection{Análise Estatística}

A análise dos dados foi realizada em microcomputador utilizando-se o pacote estatístico SPSS - Statistical Package for Social Sciences (versão 16.0). Para comparação de variáveis qualitativas, como freqüências e proporções, foi utilizado o teste de qui-quadrado ou exato de Fisher, se necessário. Para comparação de dados quantitativos, foram utilizados os testes de Mann-Whitney ou t de Student. A análise multivariada foi executada utilizando-se o teste de regressão logística. $O$ valor de significância estatística foi estabelecido em $5 \% \quad(p<0,05)$. 


\section{RESULTADOS}

\subsection{Características clínico-demográficas e hábitos da população estudada}

As pacientes do G2 (HIV-) apresentaram menor idade, maior consumo de alcóol, maior número de parceiros sexuais nos últimos seis meses e menor prevalência para a prática de sexo oral em relação ao G1 (HIV+). Não houve diferença entre os grupos quanto à cor da pele auto-referida, nível de escolaridade, tabagismo, presença de lesão genital macroscópica pelo HPV, DST prévia, número de parceiros sexuais na vida. As características clínico-demográficas e hábitos comportamentais da população estudada encontram-se descritas na Tabela 5.1.

Tabela 5.1 - Características clínico-demográficas e hábitos comportamentais da população estudada

\begin{tabular}{c|c|c|c|c}
\hline Dados clínicos e hábitos & população total $(\mathbf{n = 2 0 0 )}$ & HIV+ $(\mathbf{n = 1 0 0 )}$ & HIV-(n=100) & $p$ \\
\hline Idade média \pm DP & $36,17 \pm 12,09$ & $42,48 \pm 10,16$ & $30,38 \pm 9,62$ & $<0,001$ \\
\hline Cor da pele - $\mathbf{n}(\%)$ & & & & $>0,05$ \\
Branca & $99(49,5)$ & 56 & 43 & \\
Não-branca & $101(50,5)$ & 44 & 57 & \\
\hline Nível de escolaridade - $\mathbf{n}(\%)$ & & & & 0,195 \\
Fundamental incompleto & $42(21,0)$ & 27 & 15 & \\
Fundamental completo & $32(16,0)$ & 18 & 14 & \\
Médio incompleto & $10(5,0)$ & 5 & 5 & \\
Médio completo & $70(35,0)$ & 29 & 41 & \\
\hline
\end{tabular}




\begin{tabular}{|c|c|c|c|c|}
\hline Superior incompleto & $21(10,5)$ & 8 & 13 & \\
\hline Superior completo & $24(12,0)$ & 13 & 11 & \\
\hline Não relatou & $1(0,5)$ & 0 & 1 & \\
\hline Tabagismo - n (\%) & $62(31,0)$ & 27 & 35 & 0,217 \\
\hline $\begin{array}{l}\text { Etilismo - } \mathrm{n}(\%) \\
\text { Frequência ingestão alcoólica (semanas }\end{array}$ & $100(50,00)$ & 36 & 64 & $<0,001$ \\
\hline$\leq 2 x$ & $96(96,00)$ & 33 & 63 & 0,140 \\
\hline$>2 x$ & $4(4,00)$ & 3 & 1 & \\
\hline Lesão de HPV cervical macro - $\mathrm{n}(\%)$ & $32(16,00)$ & 15 & 17 & 0,847 \\
\hline DST prévia - n (\%) & $105(52,50)$ & 48 & 57 & 0,257 \\
\hline Parceiros sexuais na vida - $\mathrm{n}(\%)$ & & & & 0,563 \\
\hline$\geq 5$ & $121(60,50)$ & 63 & 58 & \\
\hline$<5$ & $79(39,50)$ & 37 & 42 & \\
\hline Parceiros sexuais (últimos 6 ) - $n(\%)$ & & & & $<0,001$ \\
\hline$\leq 1$ & $160(80,00)$ & 96 & 64 & \\
\hline 2 & $14(7,00)$ & 2 & 12 & \\
\hline$\geq 3$ & $26(13,00)$ & 2 & 24 & \\
\hline Prática de sexo oral - $\mathrm{n}(\%)$ & $130(65,00)$ & 75 & 55 & 0,005 \\
\hline
\end{tabular}

Legenda: $n=$ número de pacientes; $\mathrm{DP}=$ desvio padrão; $\mathrm{HIV=vírus} \mathrm{da} \mathrm{imunodeficiência} \mathrm{humana;}$ $\mathrm{HPV}=$ papilomavírus humano; DST=doença sexualmente transmissível, macro=macroscópica.

Nas pacientes soropositivas para o HIV, a forma de contágio relatada foi predominantemente através de relação sexual ( $96 \%$ dos casos), sendo que $2 \%$ acreditam terem se infectado através de transfusão sanguínea, 1\% via transmissão vertical e $1 \%$ por uso de drogas injetáveis. Além disso, 82 pacientes estavam sob uso de terapia antiretroviral (82\%), sendo que todas estavam sob terapia antiretroviral altamente ativa (HAART). 
Foi possível obter dados laboratoriais dos últimos 3 meses relacionados à contagem de células CD4 (céls $/ \mathrm{mm}^{3}$ ) e CV (cópias $/ \mathrm{ml}$ ) de 95 das 100 pacientes do G1 (HIV+). A maior parte das pacientes (51,57\%) apresentava CD4 $\geq 500$ céls $/ \mathrm{mm}^{3} \mathrm{e}$ com carga viral com valores inferiores ao limite de detecção do método empregado (<50 cópias $/ \mathrm{ml})$. Os dados laboratoriais referentes à contagem de CD4 e CV das pacientes do $\mathrm{G} 1(\mathrm{HIV}+)$ encontram-se descritos na Tabela 5.2.

Tabela 5.2 - Dados laboratoriais relacionados à contagem de células CD4 e carga viral obtidos nos últimos 3 meses

\begin{tabular}{c|c}
\hline Dados laboratoriais & HIV + \\
\hline $\mathrm{n}$ total & $95 / 100$ \\
\hline Contagem de CD4 (céls./mm $\left.{ }^{3}\right) \mathbf{n}(\%)$ & \\
$200-499$ & $37(38,47)$ \\
$\geq 500$ & $49(51,57)$ \\
Carga viral (cópias/ml) n (\%) & \\
Indetectável (<50cópias/ml) & $55(57,89)$ \\
$<10000$ & $22(23,15)$ \\
$\geq 10000$ & $18(18,94)$ \\
\hline
\end{tabular}

\subsection{Prevalência de DNA-HPV na mucosa oral e subtipos encontrados pela captura híbrida 2}

Nas amostras de mucosa oral, foi observada a presença de DNA do HPV em 13 pacientes, sendo $11 \%$ das pacientes do $\mathrm{G} 1(\mathrm{HIV}+)$ e $2 \%$ das pacientes do $\mathrm{G} 2$ 
(HIV-) $(p=0,02)$ (Gráfico 5.1). Avaliando-se os subtipos virais nas 13 pacientes com positividade oral para o HPV, 9 foram de alto risco e 4 de baixo risco. No G1 (HIV+), das 11 pacientes com positividade da mucosa oral para HPV, 7 (63,6\%) apresentaram HPV de alto risco e $4(36,4 \%)$, HPV de baixo risco. No G2 (HIV-), as 2 pacientes (100\%) apresentaram subtipos virais de alto risco. Houve maior prevalência de HPV de alto risco na mucosa oral das pacientes do G1 (HIV+), no entanto, o resultado não foi estatisticamente significativo $(p=0,08)$ (Gráfico 5.2). A análise semi-quantitativa revelou que a média dos valores positivos observados foi de $2,19 \pm 1,25)$.

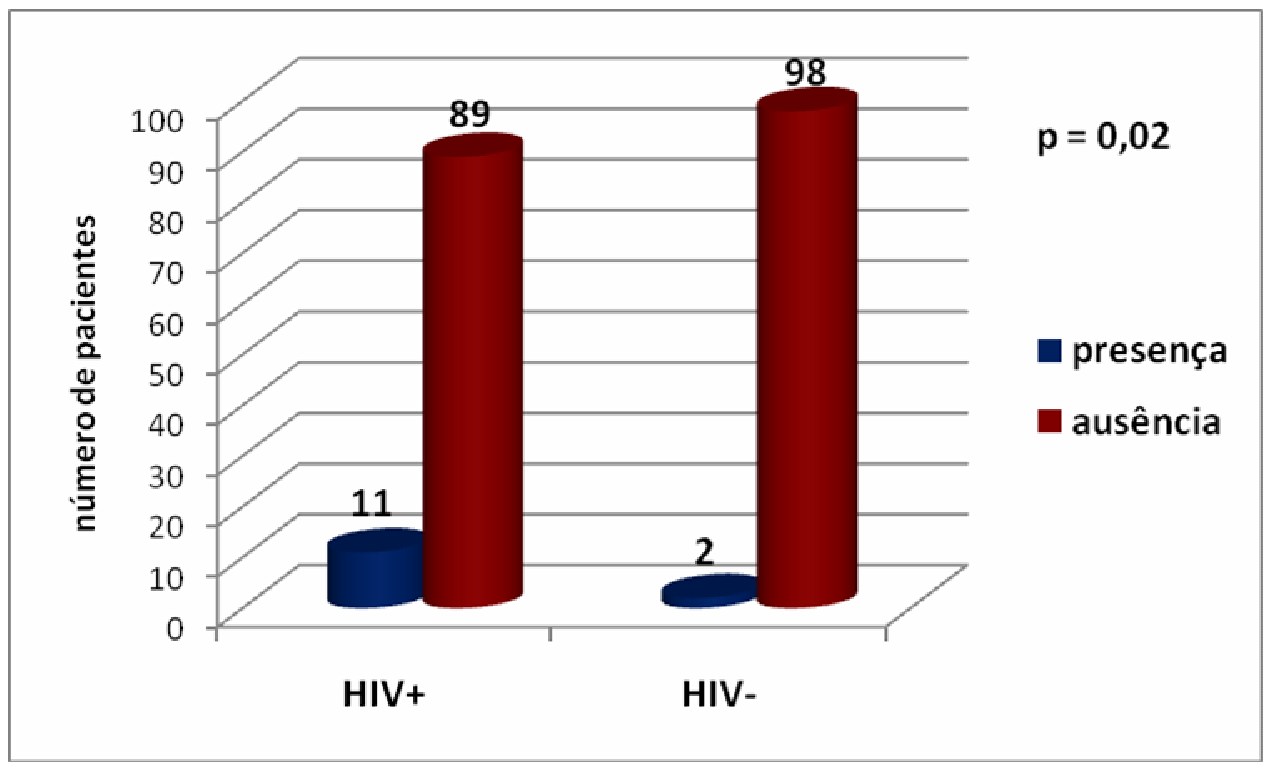

Gráfico 5.1 - Prevalência de DNA-HPV na mucosa oral em pacientes HIV+ e HIV-. 


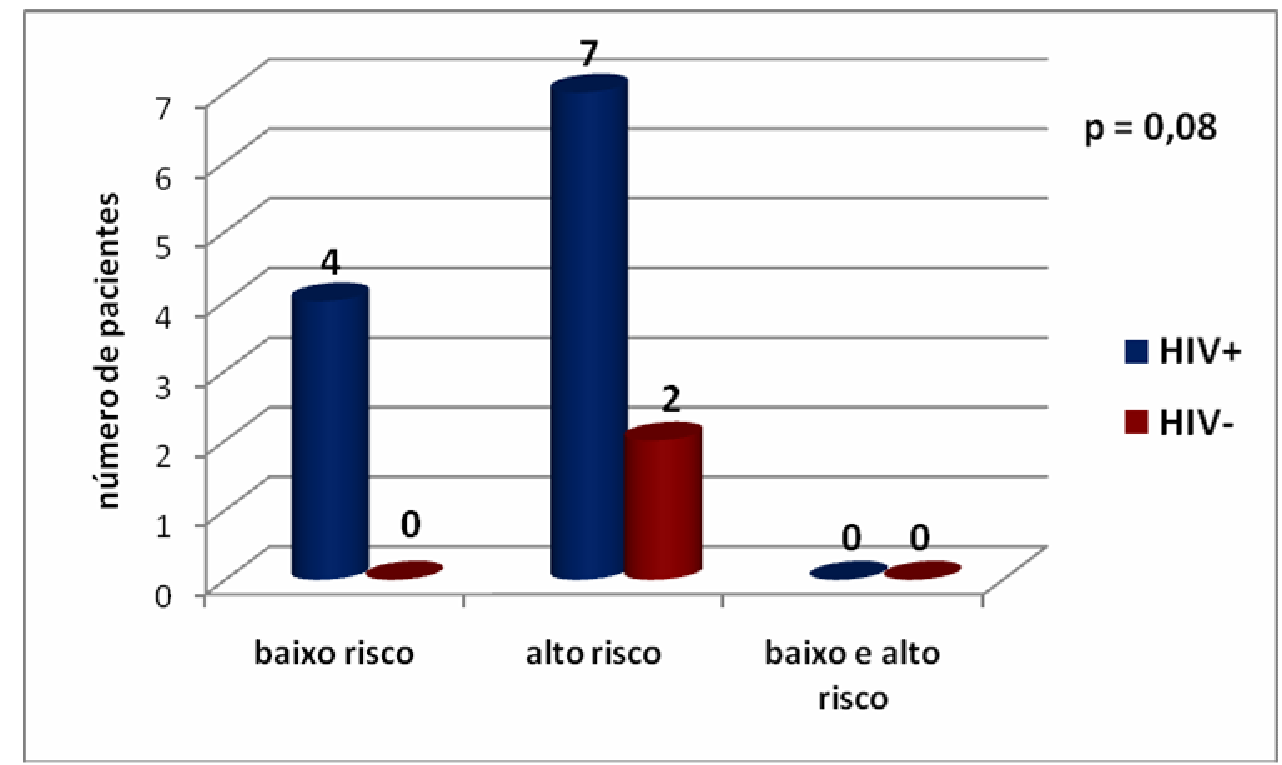

Gráfico 5.2 - Distribuição das pacientes quanto aos subtipos virais de HPV na mucosa oral

\subsection{Prevalência de HPV no colo uterino e subtipos detectados pela captura} híbrida 2

Das pacientes incluídas nesse estudo, 86 (43\%) exibiram presença de DNA do HPV no colo uterino, sendo 41 pacientes do G1 (HIV+) e 45 do G2 (HIV-) (p= 0,67). Com relação ao subtipo viral, $24 \%$ das pacientes do G1 (HIV+) apresentaram HPV de baixo risco e $36 \%$ apresentaram HPV de alto risco, sendo que destas pacientes, 17\% apresentaram genótipos de HPV de alto e baixo risco. No G2 (HIV-), $22 \%$ das pacientes apresentaram HPV de baixo risco e $41 \%$, HPV de alto risco, sendo a infecção por HPV de alto e baixo risco oncogênico observada em 23 pacientes. Não houve diferença entre os grupos em relação aos subtipos virais 
$(p=0,87)$ (Gráficos 5.3 e 5.4). A análise semi-quantitativa revelou que a média dos valores positivos observados foi de $289,14 \pm 593,66$ ).

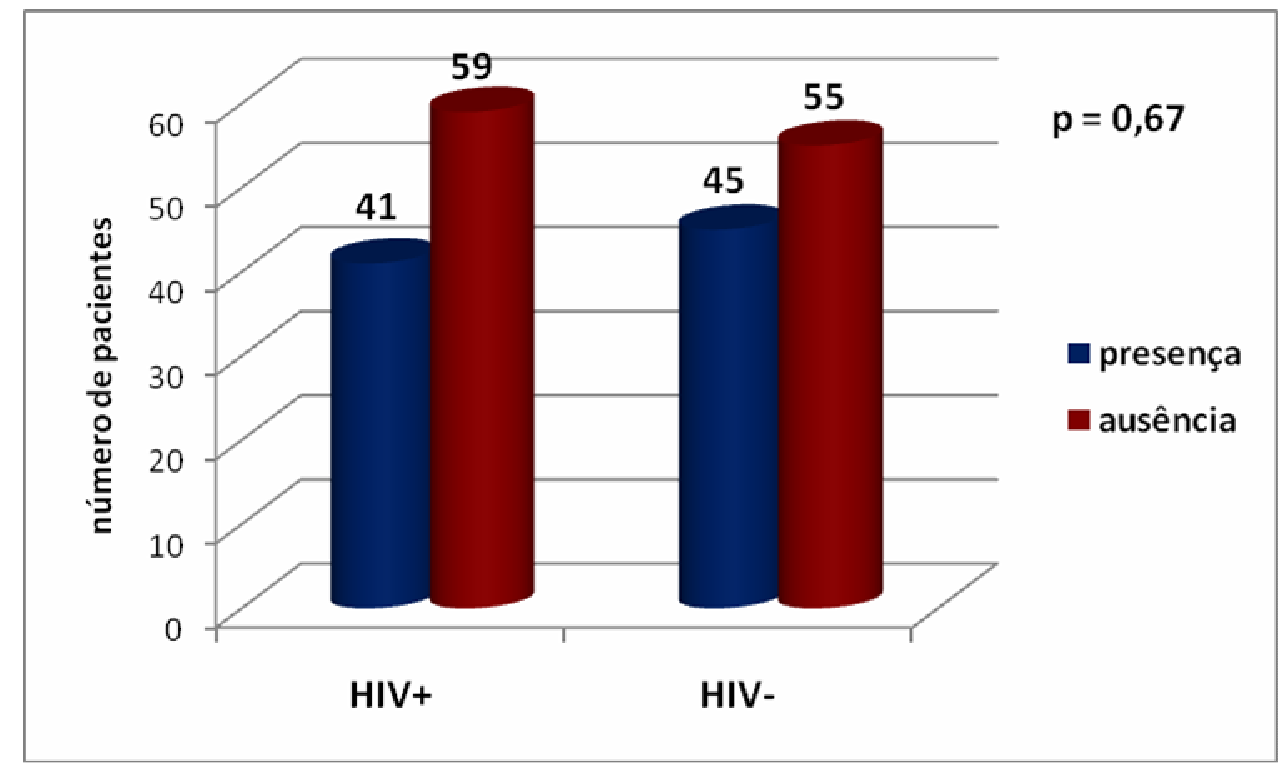

Gráfico 5.3 - Prevalência de DNA-HPV no colo uterino em pacientes HIV+e HIV-

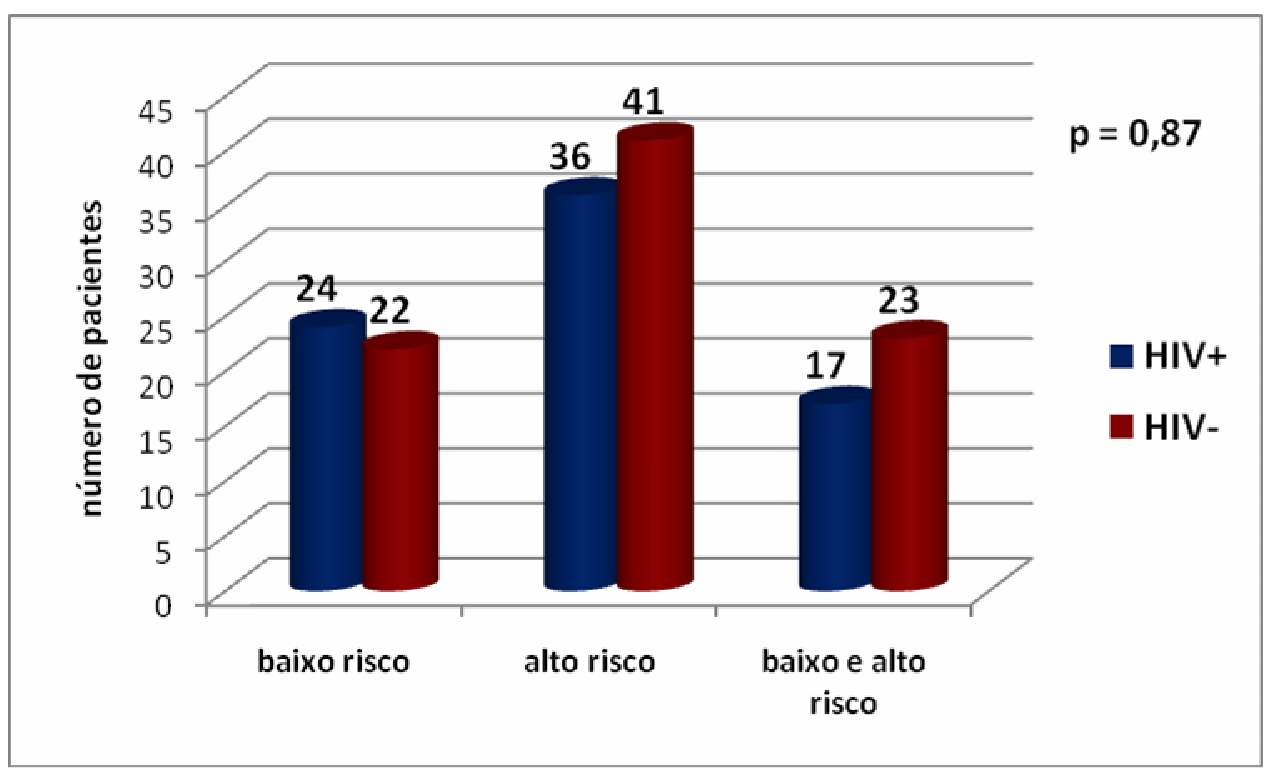

Gráfico 5.4 - Distribuição das pacientes quanto aos subtipos virais de HPV na mucosa cervical 


\subsection{Correlação entre a presença de DNA-HPV na mucosa oral e no colo uterino}

Não houve correlação entre a presença de HPV no colo uterino e na mucosa oral das pacientes estudadas ( $p>0,05)$. No $\mathrm{G} 1(\mathrm{HIV}+)$, dentre as 41 pacientes com presença de DNA-HPV no colo uterino, 5 pacientes apresentaram DNA-HPV na mucosa oral. Dentre as 59 pacientes com ausência de DNA-HPV cervical, 6 apresentaram DNA-HPV na boca. No G2 (HIV-), das 45 pacientes com presença de DNA-HPV cervical, 1 apresentou DNA-HPV na boca. Da mesma forma, das 55 pacientes com teste negativo para HPV no colo uterino, 1 exibiu presença de DNAHPV na boca. Não foi observada correlação entre a presença de HPV na boca e no colo uterino nem para o grupo $1(p=0,75)$, nem para o grupo $2(p=0,89)$ (Gráficos 5.5 e 5.6)

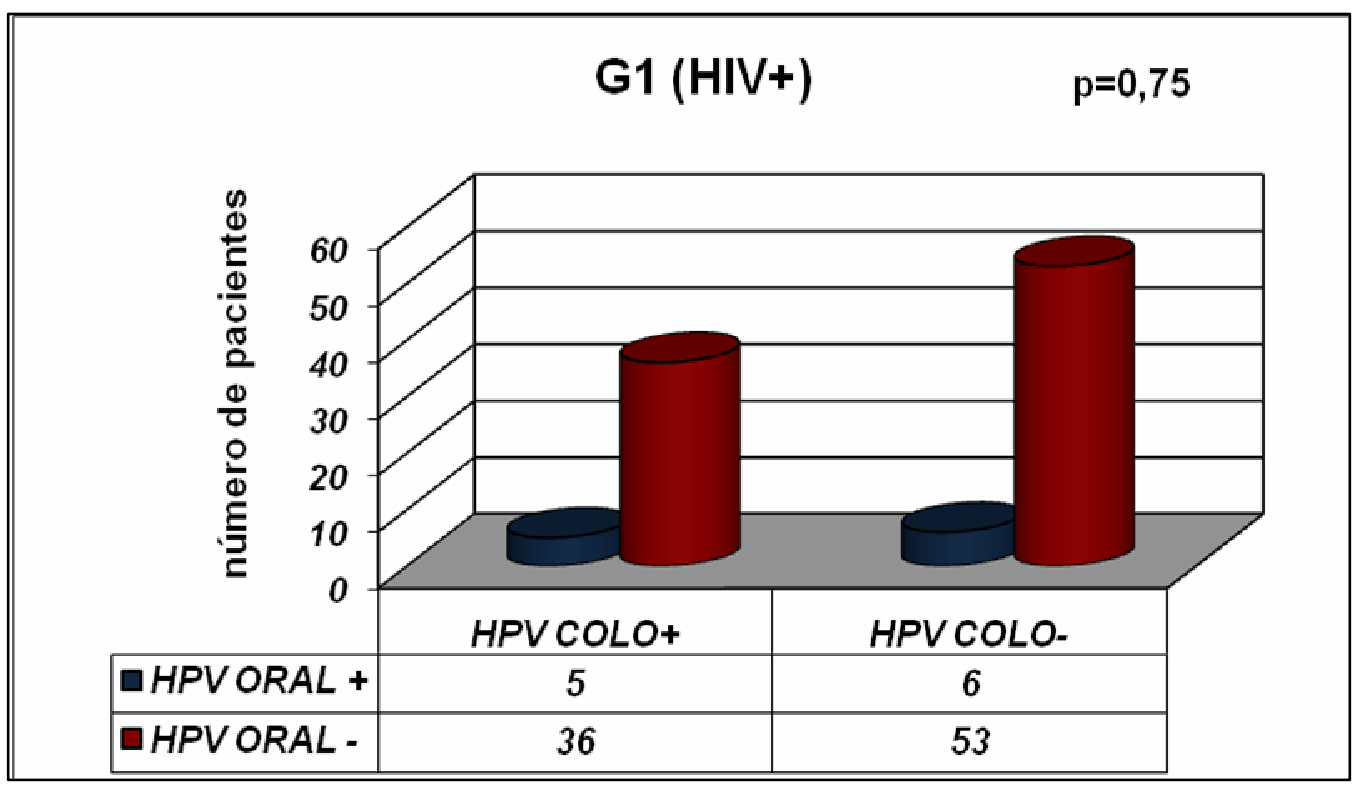

Gráfico 5.5 - Distribuição das pacientes do G1 (HIV+) quanto à presença de DNAHPV no colo uterino e na mucosa oral 


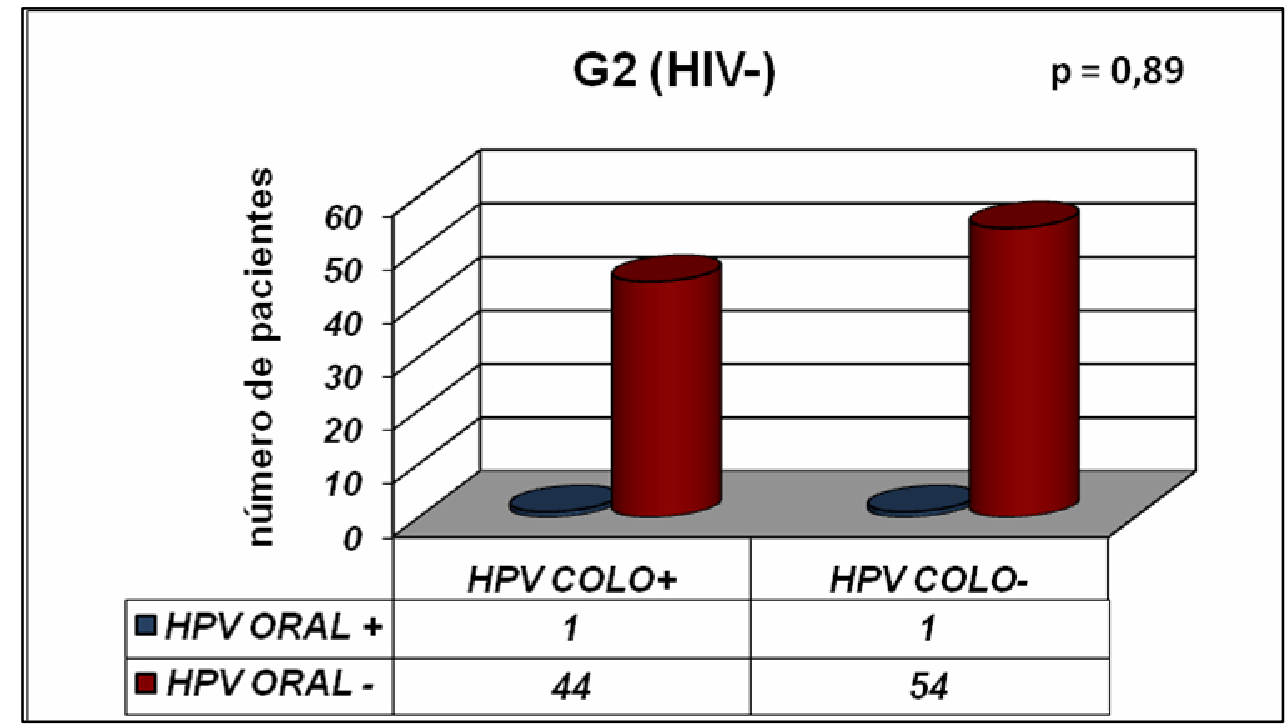

Gráfico 5.6 - Distribuição das pacientes do G2 (HIV-) quanto à presença de DNAHPV no colo uterino e na mucosa oral

Quando consideramos apenas as pacientes com presença de HPV nas duas mucosas concomitantemente, observamos que a presença do HPV de alto risco é mais comum que a de baixo risco, simultaneamente. Contudo, o número reduzido de pacientes com presença de HPV nas mucosas oral e cervical concomitante $(n=6)$ obtido em nosso estudo, não permitiu uma avaliação estatística adequada.

Os dados relativos à distribuição das pacientes com presença de HPV oral em relação à presença de HPV no colo, prática de sexo oral, valores referentes a CD4 e CV encontram-se dispostos na Tabela 5.3. 
Tabela 5.3- Distribuição das pacientes com presença de HPV oral quanto a hábitos sexuais, presença de HPV no colo

\begin{tabular}{c|c|c|c|c|c|c}
\hline $\begin{array}{c}\text { Número } \\
\text { inclusão }\end{array}$ & Grupo & $\begin{array}{c}\mathrm{HPV} \\
\text { colo }\end{array}$ & $\begin{array}{c}C D 4 \\
\left(\text { céls } / \mathrm{mm}^{3}\right)\end{array}$ & $\begin{array}{c}\text { PARC } \\
6 M\end{array}$ & $\begin{array}{c}\mathrm{CV} \\
\text { (cópias/ml) }\end{array}$ & $\begin{array}{c}\text { Sexo } \\
\text { oral }\end{array}$ \\
\hline 194 & 1 & - & 1528 & 0 & IND & + \\
\hline 188 & 1 & - & 699 & 1 & IND & + \\
\hline 178 & 1 & + & 166 & 1 & 192687 & + \\
\hline 172 & 1 & - & 416 & 0 & IND & + \\
\hline 142 & 1 & - & 322 & 1 & 31369 & + \\
\hline 131 & 1 & - & 560 & 0 & IND & + \\
\hline 130 & 1 & + & 633 & 3 & IND & - \\
\hline 123 & 1 & + & 347 & 0 & 214 & + \\
\hline 122 & 1 & + & 1064 & 1 & IND & - \\
\hline 121 & 1 & - & 478 & 1 & IND & + \\
\hline 103 & 1 & + & 274 & 0 & 275 & + \\
\hline 101 & 2 & + & - & 4 & - & + \\
\hline 69 & 2 & - & - & 3 & - & - \\
\hline
\end{tabular}

Legenda: - : negativo; + : positivo; IND: indetectável; PARC6M : número de parceiros sexuais nos últimos 6 meses

\section{5 citologia em base líquida}

Os resultados citológicos da mucosa oral demonstraram que nenhuma paciente apresentou resultado suspeito ou positivo para neoplasia.

Os resultados referentes à citologia do colo uterino demonstraram que 47 pacientes $(23,5 \%)$ apresentaram resultados suspeitos ou positivos para neoplasia, sendo 23 pacientes do G1 (HIV+) e 24 pacientes do G2 (HIV-) (p>0,05) (Gráfico 5.7). 


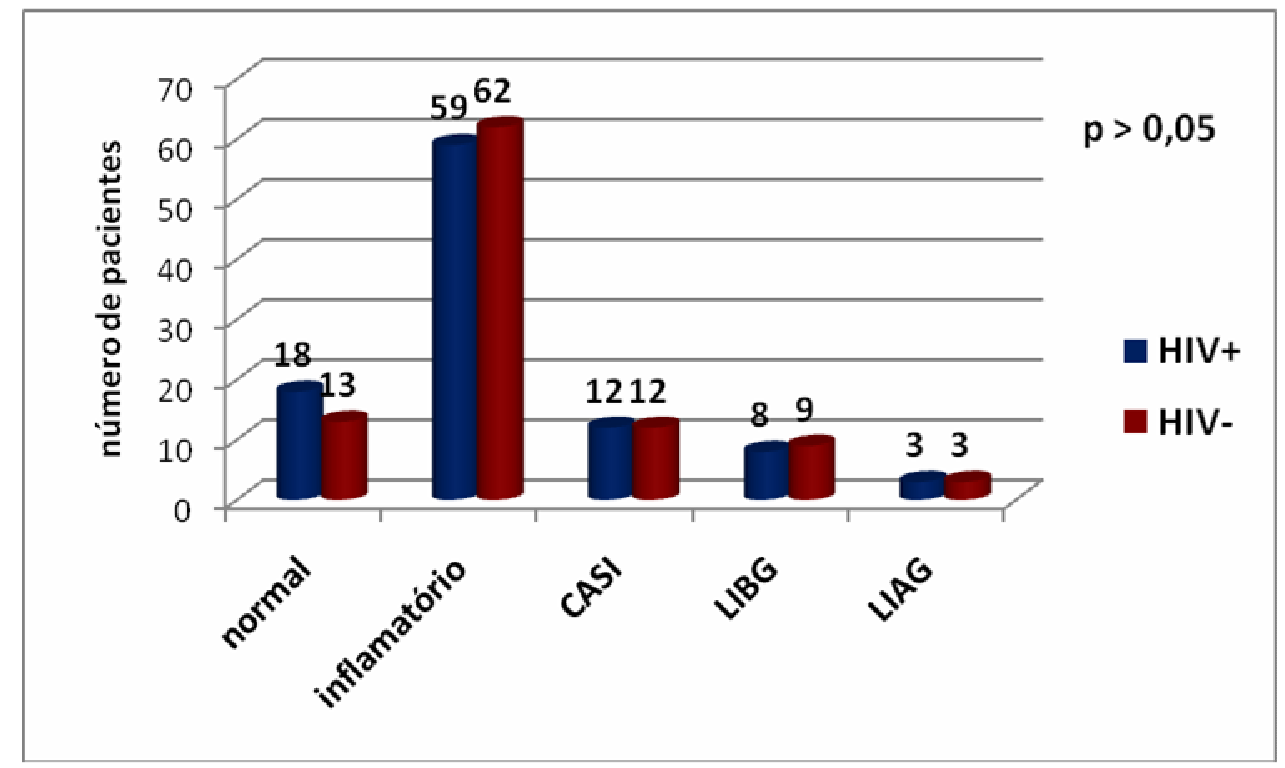

Gráfico 5.7 - Resultados do exame citológico para amostras cervicais das pacientes do G1 (HIV+) e do G2 (HIV-).

\subsection{Análise das variáveis associadas à maior presença de DNA-HPV na mucosa oral}

As seguintes variáveis não apresentaram associação com a presença de DNA-HPV na mucosa oral: presença de lesão macroscópica genital, cor da pele auto-referida, história de DST prévia, número de parceiros sexuais (em toda a vida e nos últimos 6 meses), sexo oral, uso de drogas injetáveis, tabagismo, consumo de álcool. As variáveis analisadas somente para o G1 (HIV+): forma de contágio, terapia em uso e contagem de células CD4 e CV também não apresentaram associação com a presença de HPV oral. 
A análise univariada revelou associação entre sorologia positiva para HIV e presença de DNA-HPV na mucosa oral $(p=0,018)$. Além disso, as pacientes do $\mathrm{G} 1$ $(\mathrm{HIV}+)$ com baixo nível educacional apresentaram associação com a presença de DNA-HPV oral $(p=0,02)$.

O modelo de regressão múltipla foi realizado com o objetivo de avaliar associações entre variáveis demográficas e hábitos comportamentais e a presença de infecção oral pelo HPV. Apenas a sorologia positiva para HIV demonstrou estar associada à presença de HPV-DNA na boca, independente das outras variáveis. Nas pacientes do G1 (HIV+), a chance de ocorrência de DNA-HPV na mucosa oral foi aproximadamente 6 vezes maior que nas pacientes do G2 (HIV-) (OR=6,06; $95 \% I C=1,31-28,07 ; p=0,02)$.

\subsection{Análise das variáveis associadas à maior presença de DNA-HPV no colo uterino}

As seguintes variáveis não apresentaram associação com maior risco de presença de DNA-HPV no colo uterino: nível educacional, presença de DST prévia, número de parceiros sexuais (em toda a vida e nos últimos 6 meses), uso de drogas injetáveis ilícitas, tabagismo e consumo de álcool. As variáveis analisadas apenas para o G1 (HIV+): forma de contágio, terapia em uso, contagem de CD4 e CV também não demonstraram relação com a infecção cervical pelo HPV. 
$\mathrm{Na}$ análise univariada, as seguintes variáveis exibiram associação com a presença de DNA-HPV na mucosa cervical no $\mathrm{G} 1(\mathrm{HIV}+)$ isoladamente: cor negra $(0,023)$ e não-prática de sexo oral $(p=0,027)$. No G2 (HIV-) isoladamente, a idade precoce $[(p=0,014)$, (Gráfico 5.8)] e a presença de lesão macroscópica de HPV genital $(p=0,01)$ foram associadas à presença de DNA-HPV no colo uterino.

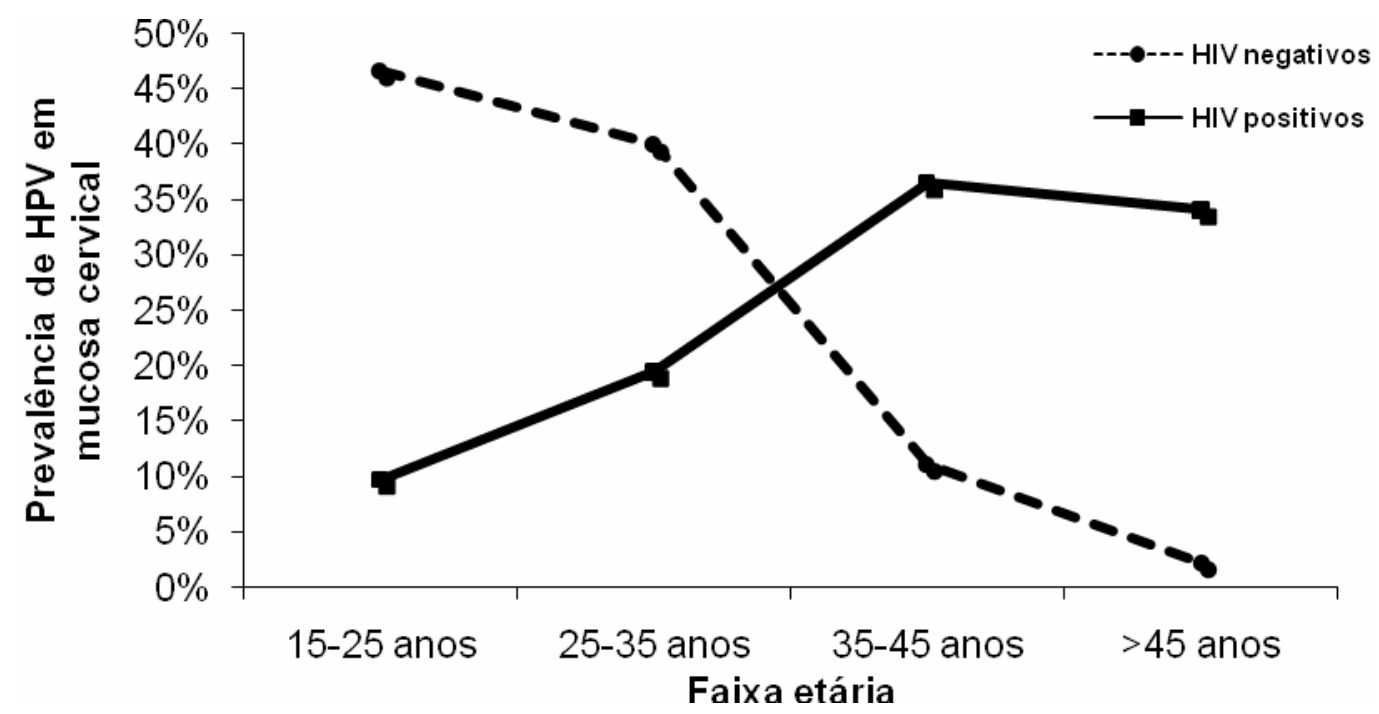

Gráfico 5.8 - Presença de DNA-HPV cervical de acordo com a idade

A única variável que apresentou associação com a presença de DNA-HPV no colo uterino nos 2 grupos segundo a análise univariada foi a citologia de colo suspeita ou positiva para neoplasia $[p=0,009$ para $\mathrm{G} 1(\mathrm{HIV}+)$ e $\mathrm{p}<0,001$ para $\mathrm{G} 2$ (HIV-)].

$\mathrm{Na}$ análise multivariada, tanto para o grupo G1 (HIV+) como para o G2 (HIV+), apenas a variável citologia de colo suspeita ou positiva para neoplasia demonstrou ser um fator de risco independente para a presença de HPV-DNA no colo. 


\section{DISCUSSÃO}

Nossos resultados mostraram que não houve associação entre a infecção pelo HPV nas mucosas cervical e oral. Além disso, dentre as 200 mulheres estudadas, quase a metade $(43,0 \%)$ exibiu infecção pelo HPV em colo uterino, não havendo correlação com a sorologia para HIV. Em relação à infecção oral por HPV, 13 pacientes $(6,5 \%)$ apresentaram resultados positivos, sendo observada maior prevalência em pacientes HIV+ (84,6\%).

A literatura pertinente sobre a prevalência do HPV na mucosa oral livre de lesão apresenta resultados conflitantes, variando de 1,2\% até 50,0\% (BAUER et al., 1991; FURRER et al., 2006, GONZÁLEZ-LOSA et al., 2008, LUO; ROAN; LIU, 2007, MILLER; JOHNSTONE, 2001). Da mesma forma, os resultados relativos à prevalência de HPV em mucosa uterina são contraditórios com valores entre 43,0\% e 98,0\% (CAÑADAS et al., 2004; FAKHRY et al., 2006; JAMIESON et al., 2002; LEVI et al., 2002a; LEVI et al., 2002b; MINKOFF et al., 1999, PALEFSKY et al., 1999).

As discordâncias entre os resultados publicados, tanto para amostras orais como para as de colo uterino, podem ser atribuídas à utilização de diferentes metodologias, características epidemiológicas diversas dos grupos estudados, variação no local da coleta e tamanho das amostras, dentre outros fatores (ANAYASAAVEDRA et al., 2008; GONZÁLEZ-LOSA et al., 2008; LUO; ROAN; LIU et al., 2007; SIMONATO et al., 2008; LEVI et al. 2004). 
Tanto nossos resultados quanto a literatura demonstram maior frequência de infecção pelo HPV na região cervical em relação à mucosa oral. Este fato pode ser explicado, em parte, pelas características histológicas mais vulneráveis do colo uterino. A mucosa cervical apresenta dois tipos epiteliais distintos: o epitélio colunar simples da endocérvice e o epitélio pavimentoso estratificado da ectocérvice, sendo que o epitélio de transição apresenta células basais expostas. Para que o HPV penetre no epitélio, é necessária a presença de microlesões ou exposição das células basais, situação que torna esse tecido mais vulnerável à infecção pelo HPV que a mucosa oral (HORMIA et al., 2005). Além disso, alguns autores sugerem que proteínas presentes na saliva, como lisozimas, lactoferrina, imunoglobulina A $(\lg A)$ e citocinas podem representar componente protetor, prevenindo o desenvolvimento de infecção oral pelo HPV, porém esse fato ainda não é bem estabelecido sendo necessários estudos adicionais que comprovem essa hipótese (GONÇALVES et al., 2006).

Outro achado importante do nosso estudo foi a prevalência de DNA-HPV significativamente maior em amostras orais de pacientes HIV+ $(11,0 \%)$ em relação às pacientes HIV- (2,0\%). Observou-se que as pacientes HIV+ apresentaram aproximadamente seis vezes mais chance de contraírem HPV na boca que as pacientes HIV-. Esses resultados corroboram os achados de Coutlée et al. (1997) e de Kreimer et al. (2004). Estudos apontam que mulheres HIV+ com contagem de células CD4 $\leq 200$ céls $/ \mathrm{mm}^{3}$ apresentam maior risco para infecção pelo HPV oral e cervical (D'SOUZA et al., 2007b; KREIMER et al., 2004; LEVI et al., 2002b; PALEFSKY et al., 1999; RICHTER et al., 2008). Giraldo et al. (2006) sugeriram que uma inadequada resposta imune pode favorecer a colonização pelo HPV em áreas extra-genitais. Em contraste, Cameron et al. (2005) observaram que o tratamento 
para o HIV, mais que a imunossupressão em si, parece estar relacionado à infecção oral pelo HPV em indivíduos HIV+.

Entretanto, se a infecção pelo HPV está relacionada ao grau de imunocompetência do indivíduo (PALEFSKY et al., 1999), a situação esperada é que a presença de HPV na boca esteja associada à contagem de células CD4 e CV do HIV. Porém, os resultados deste estudo não demonstraram associação entre essas variáveis e a presença de DNA-HPV oral, indicando que pode haver outro mecanismo envolvido na infecção tanto oral quanto cervical pelo HPV nessas pacientes HIV+.

Esse mecanismo pode envolver a ação local de imunoglobulinas, embora as informações dispostas na literatura ainda não sejam suficientes para explicar os mecanismos fisiopatológicos envolvidos nessa instalação. Porém, alguns autores citam a resposta imune local reduzida como fator predisponente a esta infecção (ADAMOPOULOU et al., 2008). Mulheres com baixos níveis de IgA foram mais suscetíveis à colonização da mucosa oral e genital pelo HPV. Possivelmente, a IgA inibe a aderência de patógenos na membrana celular e, além disso, a IgA tem a capacidade de neutralizar o vírus no meio intracelular, onde usualmente os anticorpos oferecem pequena proteção (GONÇALVES et al., 2006).

Quanto aos nossos resultados da análise semi-quantitativa pela $\mathrm{CH} 2$ na mucosa oral, o número de cópias virais encontrado foi baixo, independentemente do status sorológico para o HIV. O estudo mostrou, ainda, que nenhuma paciente apresentou lesão macroscópica sugestiva de infecção pelo HPV na cavidade oral, a despeito da positividade da $\mathrm{CH}$ para presença de DNA-HPV. Este dado sugere que 
o HPV pode estar presente em sua forma latente, sem replicação viral, preservando as características histológicas normais do epitélio acometido.

Baseado no conhecimento de que as amostras orais positivas para HPV apresentam poucas cópias de DNA desse vírus, as pesquisas para identificação de DNA-HPV na cavidade oral devem ser realizadas com utilização de testes de alta sensibilidade, especificidade e acurácia (HORMIA et al., 2005, XAVIER et al., 2007, CAMPISI; GIOVANELLI, 2009).

Com relação à frequência de DNA-HPV no colo uterino, no presente estudo foi observada prevalência similar desse vírus nas pacientes HIV+ $(41 \%)$ e HIV(45\%) embora a literatura pertinente aponta para maior prevalência de DNA-HPV cervical em pacientes HIV+ em relação a pacientes HIV- (JAMIESON et al., 2002; KREIMER et al., 2004; LEVI et al., 2002a; LEVI et al., 2004; PALEFSKY et al., 1999; PALEFSKY, 2006).

Essa divergência de nossos resultados em relação à literatura pode ser atribuída à presença de riscos adicionais para a infecção pelo HPV no grupo de pacientes HIV-, uma vez que apresentavam menor faixa etária e maior número de parceiros sexuais nos últimos 6 meses. Já foi bem estabelecido na literatura que pacientes mais jovens e com maior número de parceiros sexuais apresentam maior risco para desenvolvimento de HPV genital (GRINSZTEJN et al., 2009; PALEFSKY et al., 1999, RAMA et al., 2008,).

De fato, neste estudo observou-se maior prevalência de DNA-HPV na região cervical de pacientes HIV- em mulheres com idade inferior a 35 anos. Essa frequência mostrou marcante declínio com o aumento da idade, o que pode ser observado no Gráfico 5.10. Outros trabalhos corroboram os nossos achados 
(CAÑADAS et al., 2004; D'SOUZA et al., 2007b), sendo que o mecanismo exato do declínio da prevalência do HPV relacionado à idade ainda não é bem compreendido (PALEFSKY et al., 1999). De acordo com Rama et al. (2008), a redução na prevalência do HPV genital com a elevação da idade estaria relacionada à diminuição da atividade sexual, fato que tornaria as mulheres menos expostas a esse vírus. Entretanto, outros estudos relatam queda na prevalência da infecção por HPV com o avanço da idade mesmo em mulheres que mantêm vida sexual ativa, resultado semelhante aos nossos achados.

Diante dessa evidência, os resultados sugerem que a diminuição na prevalência de HPV com o avançar a idade independe do comportamento sexual e parece estar mais relacionada ao desenvolvimento de imunidade tipo-específica à infecção por esse vírus. Essa proteção pode ser decorrente da aquisição de imunidade celular e/ou produção sistêmica constante de anticorpos contra o HPV, contribuindo para a resposta local contra novas infecções (CAÑADAS et al., 2004). Entretanto, no presente estudo não foi observada diminuição na prevalência de infecção cervical pelo HPV em relação à idade nas pacientes HIV+, provavelmente devido a funcionamento inadequado do sistema imunológico dessas pacientes.

Os resultados deste estudo demonstraram que os subtipos de HPV foram semelhantes com relação ao potencial oncogênico tanto entre os grupos estudados quanto em relação aos sítios analisados, corroborando os achados de Jamieson et al. (2002). Houve, no entanto, uma tendência à maior prevalência de HPV de alto risco oncogênico na mucosa oral de pacientes HIV+.

Dentre as técnicas disponíveis para a identificação do DNA-HPV, a PCR e a $\mathrm{CH} 2$ se destacam exibindo as maiores sensibilidade e especificidade (MAYRAND et 
al., 2007; NOVAES; NOVAES; SIMÃO-BARBOSA, 2006; SODERLUND-STRAND et al. ,2005), sendo consideradas padrão-ouro para o diagnóstico de DNA-HPV na mucosa de colo uterino.

A $\mathrm{CH} 2$ representa um método validado e considerado de alta especificidade e sensibilidade pela comunidade científica para avaliação de amostras de mucosa cervical. No entanto, para a análise de amostras provenientes de mucosa oral, este método ainda é pouco utilizado. Nossos resultados indicaram que a $\mathrm{CH} 2$ representa opção para pesquisa de DNA-HPV na mucosa oral, tendo em vista que corroboram os achados já relatados pela técnica da PCR (ADAMOUPOULOU et al., 2008; ANAYA-SAAVEDRA et al. 2008; CAÑADAS et al., 2004; GIRALDO et al., 2006; KREIMER et al., 2004; MAGI et al., 2006; XAVIER et al., 2007).

No presente estudo, as células superficiais da cavidade oral foram coletadas especificamente da mucosa jugal de ambos os lados. Este fato pode ser considerado uma limitação do estudo, uma vez que o vírus pode estar presente em outros sítios, como língua, palato e lábio. Portanto, a coleta de células de múltiplos sítios pode fornecer informação mais fidedigna da prevalência do vírus na cavidade oral. Este fato representa espaço para continuidade de pesquisa nesta área.

Com relação a pacientes $\mathrm{HIV}_{+}$, alguns autores acreditam que, após a introdução da HAART, houve diminuição expressiva na quantidade de lesões orais, incluindo aquelas provocadas por HPV (GREENSPAN et al., 2001; HODGSON; GREENSPAN; GREENSPAN, 2006). Cameron et al. (2005), ao contrário, sugerem que a prevalência de condilomas orais tem aumentado em indivíduos HIV+ a partir da introdução da HAART e justificam que a combinação das drogas usadas para tratar o HIV parece ser fator de risco adicional para infecção por esse vírus na boca. 
Outros estudos indicam que pacientes HIV+ apresentam infiltração linfocítica das glândulas salivares maiores, resultando em hipossalivação com conseqüente redução dos níveis de imunoglobulinas (NAVAZESH et al., 2003; D’SOUZA et al., 2007a). Esses autores afirmam, ainda, que a HAART propicia uma diminuição adicional da salivação através de mecanismo possivelmente causado por efeito químico anti-secretório nas células acinares, propiciando o desenvolvimento de xerostomia. Além da diminuição de imunoglobulinas salivares, nossas observações clínicas sugerem que o ressecamento da mucosa oral a torna mais friável, favorecendo o aparecimento de microerosões que podem favorecer a infecção pelo HPV. Além disso, essas pacientes apresentariam, ainda, diminuição de outras proteínas salivares que poderiam estar relacionadas à infecção oral pelo HPV. Essa constatação abre discussão e sugere a realização de novos estudos que comprovem ou refutem a constatação explicitada.

Em relação à correlação entre a infecção pelo HPV nas mucosas oral e cervical, a literatura ainda é carente de pesquisas que avaliam a infecção pelo HPV em ambos os sítios num mesmo momento. Alguns trabalhos demonstraram alta prevalência de HPV na mucosa oral de pacientes com lesão genital macroscópica comparado a pacientes sem lesão genital (GIRALDO et al., 2006). Fakhry et al. (2006) observaram que infecção oral isolada é relativamente incomum, sendo que a maioria das mulheres com infecção oral pelo HPV também apresentou infecção cervical. Enquanto outros não observaram correlação entre os subtipos de HPV encontrados na boca e no colo uterino de pacientes (RICHTER et al., 2008; CAÑADAS et al., 2004). 
O mecanismo de transmissão do HPV para a cavidade oral permanece ainda parcialmente desconhecido. O contato oro-genital tem sido considerado o modo principal de transmissão de HPV para a cavidade oral (CAMPISI; GIOVANELLI, 2009), mas outras teorias incluem: transmissão perinatal, auto-contaminação e transmissão boca-a-boca (GIRALDO et al., 2006; CAMPISI et al., 2009). Em contraste com a literatura, não foi observada associação estatisticamente significativa entre a prática de sexo oral e a infecção oral por HPV no presente trabalho.

Alem da idade precoce e da infecção pelo HIV previamente discutidos, outros fatores de risco descritos na literatura para infecção cervical por HPV incluem: comportamento sexual, cor de pele, hábitos de tabagismo e alcoolismo, história previa de lesões genitais por HPV, dentre outros (CAÑADAS et al., 2004; D’SOUZA et al., 2007b; KREIMER et al., 2004). Contudo, os dados deste estudo referentes ao comportamento sexual de risco, como maior número de parceiros sexuais e realização de sexo oral, não apresentaram associação com infecção por HPV na mucosa oral.

Com relação à cor da pele, a literatura aponta que as mulheres afroamericanas apresentam maior prevalência de infecção genital pelo HPV. Nesse estudo, observou-se que as pacientes não-brancas do G1 (HIV+) apresentaram maior prevalência de DNA-HPV cervical apenas na análise univariada. Quando realizada a análise multivariada, a cor da pele não foi fator de risco independente para a infecção pelo HPV. A maior prevalência de DNA-HPV nas mulheres HIV+ afro-americanas pode ser causada por maior frequência de haplótipos do complexo 
de histocompatibilidade principal nessas pacientes, levando a resposta imune debilitada (PALEFSKY et al., 1999).

Com relação aos hábitos de tabagismo e etilismo, nesse estudo não foi observada associação entre estes hábitos e a presença de DNA-HPV em ambos os sítios estudados. Esses resultados estão de acordo com os achados de Gillison et al., 2008. Alguns estudos demonstram que o tabagismo crônico leva a aumento da queratinização nas superfícies mucosas da cavidade oral, o que as tornaria mais resistentes a pequenos traumas e menos susceptíveis à infecção das células pelo HPV. Outros trabalhos, ao contrário, acreditam que a disfunção imune relacionada ao cigarro pode facilitar a infecção pelo HPV, impedindo a habilidade do indivíduo em eliminar a infecção ou facilitando a reativação de infecção latente. Alguns estudos demonstraram que o tabagismo diminui significativamente a quantidade e função das células de Langerhans, que são responsáveis pela ativação da imunidade celular local contra o HPV (BARYON et al., 1998; D’SOUZA et al., 2007).

Por fim, a literatura ainda é bastante controversa e limitada em relação à infecção oral pelo HPV e estudos longitudinais são necessários, especialmente em populações imunodeficientes, a fim de se elucidar o mecanismo envolvido no desenvolvimento de infecção oral associada ou não à imunossupressão. 


\section{CONCLUSÕES}

- Não houve correlação entre a presença de DNA-HPV no colo uterino e na mucosa oral;

- A sorologia positiva para o HIV representou fator independente associado à infecção oral pelo HPV. 


\section{REFERÊNCIAS ${ }^{1}$}

Adamopoulou M, Vairaktaris E, Panis V, Nkenke E, Neukam FW, Yapijakis C. HPV detection rate in saliva may dependo $n$ the immune system efficiency. In vivo 2008;22:599-602.

Anaya-Saavedra G, Ramírez-Amador V, Irigoyen-Camacho MA, García-Cuellar CM, Guido-Jiménez M, Méndez-Martínez R, et al. High association of human papillomavirus infection with oral cancer: a case-control study. Arch Med Res 2008;39:189-97.

Andrews E, Seaman WT, Webster-Cyriaque J. Oropharingeal carcinoma in nonsmokers and non-drinkers: a role for HPV. Oral Oncol 2008 epub ahead of print.

Badaracco G, Venuti A, Di Lonardo A, Scambia G, Mozzetti S, Benedetti P, et al. Concurrent HPV infection in oral and genital mucosa. J Oral Pathol Med 1998;27:130-4.

Baryon SE, Madden PH, Jenkin J. The effect of smoking on cervical epithelial immunity: a mechanism for neoplastic change? Lancet 1998;2:652-4.

Bauer HM, Ting Y, Chambers JC, Tashiro CJ, Chimera J, Reingold A, et al. Genital human papillomavirus infection in female university students as determined by a PCR-based method. JAMA 1991;265(4):472-7.

Bustos DA, Grenón MS, Benitez M, Boccardo G, Pavan JV, Gendelman H. Human papillomavirus infection in cyclosporin-induced gingival overgrowth in renal allograft recipients. J Periodontol 2001;72(6):741-4.

\footnotetext{
${ }^{1}$ De acordo com estilo Vancouver. Abreviatura de periódicos segundo base de dados MEDLINE.
} 
Cameron JE, Mercante D, O'Brien M, Gaffga AM, Leight JE, Fidel PL, et al. The impact of highly active antiretroviral therapy and immunodeficiency on human papillomavirus infection of the oral cavity of human immunodeficiency vírusseropositive patientes. Sex Transm Dis 2005;32(11):703-09.

Campisi G, Panzarella V, Giuliani M, Lajolo C, Di Fede O, Falaschini S, et al. Human papillomavirus: its identity and controversial role in oral oncogenesis, premalignant and malignant lesions. Int J Oncol 2007; 30(4):813-23.

Campisi G, Giovanelli L. Controversies surrounding human papilloma virus infection, head \& neck vs oral cancer, implications for prophylaxis and treatment. Head Neck Oncol 2009;1(1):8.

Cañadas MP, Bosch FX, Junquera ML, Ejarque M, Font R, Ordoñez E, et al. Concordance of prevalence of Human Papillomavirus DNA in anogenital and oral infections in a high-risk population. J Clin Microbiol 2004;42(3):1330-2.

Clifford GM, Smith JS, Plummer M, Munoz N, Franceschi S. Human papilomavírus types in invasive cervical cancer worldwide: a meta-analysis. $\mathrm{Br} \mathrm{J}$ Cancer 2003;88:63-73.

Coutlée F, Trottier AM, Ghattas G, Leduc R, Toma E, Sanche G, et al. Risk factors for oral human papilomavírus in adults infected and not infected with human immunodeficiency virus. Sex Transm Dis 1997;24(1):23-31.

D’Souza G, Kreimer AR, Viscidi R, Pawlita M, Fakhry C, Koch WM, et al. Casecontrol study of human papillomavirus and oropharyngeal cancer. N Engl J Med 2007;356(19):1944-56.

D’Souza G, Fakhry C, Sugar EA, Seaberg EC, Weber K, Minkoff HL, et al. Six-month natural history of oral versus cervical human papillomavirus infection. Int $\mathrm{J}$ Cancer 2007;121:143-50.

D'Souza G, Agrawal Y, Halpern J, Bodison S, Gillison ML. Oral sexual behaviors associated with prevalent oral human papillomavirus infection. J Infect Dis 2009;199(9):1263-9. 
Fakhry C, D’Souza G, Sugar E, Weber K, Goshu E, Minkoff H, et al. Relationship between prevalent oral and cervical human papillomavirus infections in human immunodeficiency virus-positive and negative women. J Clin Microbiol 2006;44(12):4479-85.

Furrer VE, Benitez MB, Furnes M, Lanfranchi HE, Modesti NM. Biopsy vs. superficial scraping: detection of human papilomavírus $6,11,16$ e 18 in potencially malignant and malignant oral lesions. J Oral Pathol Med 2006;35(6):338-344.

Gillison ML, Koch Wm, Capone RB, Spafford M, Westra WH, Wu L, et al. Evidence for a causal association between human papillomavirus and a subset of head and neck cancers. J Natl Cancer Inst 2000;92:709-20.

Gillison ML, Lowy DR. A causal role for human papillomavirus in head and neck cancer. Lancet 2004;363(9420):1488-9.

Gillison ML, D’Souza G, Westra W, Sugar E, Xiao W, Begum S, et al. Distinct factor profiles for human papillomavirus type 16-positive and human papillomavirus type 16-negative head and neck cancers. J Natl Cancer Inst 2008;100(6):407-20.

Giraldo PC, Simões JA, Daniel-Ribeiro Filho, A, Tambascia JK, Dias AL, Pacello PCC. Avaliação citológica da orofaringe de mulheres portadoras do HPV genital RBGO 1996;18:737-42.

Giraldo P, Gonçalves AKS, Pereira SAS, Barros-Mazon S, Gondo ML, Witkin SS. Human papillomavirus in the oral mucosa of women with genital human papillomavirus lesions. Eur J Obst Gyn 2006;126:104-6.

Gonçalves Ak, Giraldo P, Barros-Mazon S, Gondo ML, Aaral RL, Jacyntho C. Secretory immunoglobulin A in saliva of women with oral and genital HPV infection. Eur J Obstet Gynecol Reprod Biol 2006;124:227-31.

González-Losa MR, Manzano-Cabrera L, Rueda-Gordillo F, Hernández-Solís SE, Puerto-Solís M. Low prevalence of high risk human papillomavirus in normal oral mucosa by hybrid capture 2. Braz J Microbiol 2008;39:32-4. 
Gravitt PE, Jamshidi R. Diagnosis and management of oncogenic cervical human papillomavirus infection. Infect Dis Clin North Am 2005;19(2):439-58.

Greenspan D, Canchola A, Macphail LA, Cheikh B, Greenspan JS. Effect of highly active antiretroviral therapy on frequency of oral warts. Lancet 2001;357:1411-2.

Grinsztejn B, Veloso VG, Levi JE, Velasque L, Luz PM, FriedmanRK, et al. Factors associated with increased prevalence of human papillomavirus infection in a cohort of HIV-infected Brazilian women. Int J Infect Dis 2009;13(1):72-80.

Ha PK, Califano JA. The role of human papillomavorus in oral carcinogenesis. Crit Rev Oral Biol Med 2004;15(4):188-96.

Hennessey PT, Westra WH, Califano JA. Human papillomavirus and head and neck squamous cell carcinoma: recent evidence and clinical implications. J Dent Res 2009;88(4):300-6.

Hodgson Ta, Greenspan D, Greenspan JS. Oral lesions of HIV disease and HAART in industrialized countries. Adv Dent Res 2006;19(1):57-62.

Hormia M, Willberg J, Ruokonen H, Syrjanen S. Marginal periodontium as a potential reservoir of human papillomavirus in oral mucosa. J Periodontol 2005;76(3):358-63.

Jamieson DJ, Duerr A, Burk R, Klein RS, Paramsothy P, Schuman P, et al. Characterization of genital human papilomavírus infection in women who have or who are at risk of having HIV infection. Am J Obstet Gynecol 2002;186(1):21-7.

Karlsson R, Jonsson M, Edlund K, Evander M, Gustavsson A, Bodén E. et al. Lifetime number of partners as the only independent risk factors for human papilomavírus infection:a population-based study. Sex Transm Dis 1995;22(2):11927.

Kreimer AR, Alberg AJ, Daniel R, Gravitt PE, Viscidi R, Garret ES, et al. Oral human papillomavirus infection in adults is associated with sexual behavior and HIV serostatus. J Infect Dis 2004; 189(4):686-98. 
Kreimer AR, Clifford GM, Boyle P, Franceschi S. Human papillomavirus types in head and neck squamous cell carcinomas worldwide: a systematic review. Cancer Epidemiol Biomarkers Prev 2005;14:467-75.

Kumar K, Iver VK, Bhatla N, Kriplani A, Verma K. Comparative evaluation of smear cytology \& hybrid capture II for the diagnosis of cervical câncer. Indian J Med Res 2007;126(1):39-44.

Lee JK, Kim MK, Song SH, Hong JH, Min KJ, Kim JH, et al. Comparison of human papillomavirus detection and typing by hybrid capture 2, linear array, DNA chip, and cycle sequencing in cervical swab samples. Int J Gynecol Cancer 2009;19(2):266-72.

Levi JE, Kleter B, Quint WGV, Fink MCS, Canto CLM, Matsubara R, et al. High prevalence of human papillomavirus (HPV) infections and high frequency of multiple HPV genotypes in human immunodeficiency vírus-infected women in Brazil. J Clin Microbiol 2002a;40(9):3341-5.

Levi JE, Fink MCS, Canto CLM, Carretiero N, Matsubara R, Linhares I, et al. Human papillomavirus prevalence, viral load and cervical intraepithelial neoplasia in HIVinfected women. BJID 2002b;6(3):129-34.

Levi JE, Fernandes S, Tateno AF, Motta E, Lima LP, Eluf-Neto J, et al. Presence of multiple human papillomavirus types in cervical samples from HIV-infected women. Gynecol Oncol 2004;92:225-31.

Longatto-Filho A, Namiyama G, Castelo-Filho A, Vianna MR, Dores GB, Taromanu E. Sistema dna-citoliq (dcs): um novo sistema para citologia em base líquida aspectos técnicos. DST - J bras Doenças Sex Transm 2005; 17(1):56-61.

Luo CW, Roan CH, Liu CJ. Human papillomaviruses in oral squamous cell carcinoma and pre-cancerous lesions detected by PCR-based gene-chip array. Int J Oral Maxillofac Surg 2007;36:153-8.

Magi JC, Brito EMS, Grecco ETO, Pereira SMM, Formiga GJS. Prevalência de Papilomavirus Humano (HPV) anal, genital e oral, em ambulatório geral de coloproctologia. Rev Bras Coloproctologia 2006;26(3):233-8. 
Mayrand M, Duarte-Franco E, Rodrigues I, Walter S, Hanley J, Ferenczy A, et al. Human papillomavirus DNA versus Papanicolaou screening tests for cervicqal câncer. N Eng J Med 2007; 357(16):1579-1588.

Miller CS, Johnstone BM. Human papilomavírus as a risk factor for oral squamous cell carcinoma: a meta-analysis, 1982-1997. Oral Surg Oral Med Oral Pathol Oral Radiol Endod 2001;91:622-35.

Miller CS, White DK. Human papillomavirus expression in oral mucosa, premalignant conditions, and squamous cell carcinoma: a retrospective review of the literature. Oral Surg Oral Med Oral Pathol Oral Radiol Endod 1996;82(1):57-68.

Minkoff HL, Eisenberger-Matityahu D, Feldman J, Burk R, Clarke L. Prevalence and incidence os gynecologic disorders among women infected with human immunodeficiency virus. Am J Obstet Gynecol 1999; 180(4):824-36.

Nappi L, Carriero C, Bettocchi S, Herrero J, Vimercati A, Putignano G. Eur J Ostet Gynecol Reprod Biol 2005;121(2):226-32.

Naucler P, Ryd W, Tornberg S, Strand A, Wadell G, Elfren K., et al. Human Papillomavirus and Papanicolaou tests to screen for cervical cancer. N Eng J Med 2007; 357(16):1589-1597.

Navazesh M, Mulligan R, Barrón Y, Redford M, Greenspan D, Mario Alves M, et al. A 4-year longitudinal evaluation of xerostomia and salivary gland hypofunction in the Women's Interagency HIV Study participants. Oral Surg, Oral Med, Oral Pathol, Oral Radiol Endodont 2003; 95(6):693-698.

Novaes LCG, Novaes MRCG, Simões-Barbosa A. Diagnosis of human papillomatosis by polymerase chain reaction in cases of divergence between results of hybrid capture and Papanicolaou cytology. Braz J Infect Dis 2006;10(3):169-72.

Oliveira MC, Soares RC, Pinto LP, Costa ALL. HPV e carcinogênese oral: revisão bibliográfica. Rev Bras Otorrinolaringol 2003;69(4):553-9. 
Ostwald C, Rutsatz K, Schweder J, Schmidt W, Gundlach K, Barten M. Human papilomavirus $6 / 11,16$ and 18 in oral carcinomas and benign oral lesions. Med Microbiol Immunol 2003;192(3):145-8.

Paavonen J. Human papillomavirus infection and the development of cervical cancer and related genital neoplasias. Int J Infect Dis 2007;11:S3-9.

Palefsky JM, MInkoff H, Kalish LA, Levine A, Sacks HS, Garcia P, et al. Cervicovaginal human papillomavirus infection in human immunodeficiency virus-1 (HIV)-positive and high-risk HIV-negative women. J Natl Cancer Inst 1999;91(3):22636.

Palefsky J. Biology of HPV in HIV Infection. Adv Dent Res 2006;19:99-105.

Praetorius F. HPV-associated diseases of oral mucosa. Clinics in Dermatology 1997;15:399-413.

Quint WGV, Scholte G, Van Doom LJ, Kleter B, Smits PHM, LIderman J. Comparative analysis of human papilomavírus infections in cervical scrapes and biopsy specimens by general SPF PCR and HPV genotyping. J Pathol 2001;194:518.

Rajkumar T, Franceschi S, Vaccarella S, Gajalakshmi V, Sharmila A, Snijders PJ, et al. Role of paan chewing and dietary habits in cervical carcinoma in Chennai, India. Br J Cancer 2003;88(9):1388-93.

Rama CH, Roteli-Martins C, Derchain SFM, Longatto-Filho A, Gontijo RC, Sarian LOZ, et al. Prevalência do HPV em mulheres rastreadas para o câncer cervical. Rev Saúde Públic 2008;42(1):123-30.

Richter KL, van Rensburg EJ, van Heerden WFP, Boy SC. Human papilloma virus types in the oral and cervical mucosa of HIV-positive South African women prior to antiretroviral therapy. J Oral Pathol Med 2008;37:555-9.

Rose B, Wilkins D, Li W, Tran N, Thompson C, Cossart Y, et al. Human papillomavirus in the oral cavity of patients with and without renal transplantation. Transplant 2006;82(4):570-3. 
Simonato LE, Garcia JF, Sundefeld ML, Mattar NJ, Veronese LA, Miyahara GI. Detection of HPV in mouth floor squamous cell carcinoma and its correlation with clinicopathologic variables, risk factors and survival. J Oral Pathol Med 2008;37(10):593-8.

Schiffman M, Castle PE, Jeronimo J, Rodriguez AC, Wacholder S. Human papillomavirus and cervical cancer. Lancet 2007;370:890-907.

Sikora Ag, Morris LG, Sturgis EM. Bidirectional association of anogenital and oral cavity/pharyngeal carcinomas in men. Arch Otolaryngol Head Neck Surg 2009;135(4):402-5.

Soderlund-Strand A, Rymark P, Andersson P, Dillner J, Dillner L. Comparison between the hybrid capture II test and PCR-based human papilomavírus detection method for diagnosis and posttreatment follow-up of cervical intraepithelial neoplasia. J Clin Microbiol 2005;43(7):3260-6.

Solomon D, Davey D, Kurman R, Moriarty A, O'Connor D, Prey M, et al. The 2001 Bethesda System: terminology for reporting results of cervical cytology. JAMA 2002;287:2114-9.

Syrjänen S. Human papillomavirus infections and oral tumors. Med Microbiol Immunol 2003;192(3):123-8.

Syrjänen K, Syrjänen S, Lamberg M, Pyrhönen S, Nuutinen J. Morphological and immunohistochemical evidence suggesting human papilomavírus (HPV) involvement in oral squamous cell carcinogenesis. Int J Oral Surg 1983;12:418-24.

Syrjänen S. Human papilomavírus infections and oral tumors. Med Microbiol Immunol 2003;192(3):123-8.

Syrjänen K, Derchain S, Roteli-Martins C, Longatto-Filho A, Hammes LS, Sarian Latin American Screening Study Group. Value of conventional pap smear, liquidbased cytology, visual inspection and human papillomavirus testing as optional screening tools among latin American women $<35$ and $>0 \mathrm{r}=35$ years of age. Acta Cytol 2008;52(6):641-53. 
Walboomers JM, Jacobs MV, Manos MM, Bosch FX, Kummer JA, Shah KV, et al. Human papillomavirus is a necessary cause of invasive cervical cancer worldwide. $J$ Pathol 1999;189:12-9.

Xavier SD, Bussoloti-Filho I, Carvalho JM, Framil VMS, Castro TMPPG. Freqüência de aparecimento de Papilomavírus Humano (HPV) na mucosa oral de homens com HPV anogenital confirmado por biologia molecular. Arq Int Otorrinolaringol 2007;11(1):36-44.

Yarandi F, Shojaei H, Eftekhar Z, Izadi-Mood N. Comparison of three management strategies for patients with atypical squamous cells of undetermined significance, after six months delay: a three-year experience in na Iranian university hospital. Aust N Z J Obstet Gynaecol 2009;49(2):207-10 


\section{UNIVERSIDADE DE SÃO PAULO FACULDADE DE ODONTOLOGIA}

\section{PARECER DE APROVAÇÃO Protocolo 177/07}

Com base em parecer de relator, o Comitê de Ética em Pesquisa APROVOU o protocolo de pesquisa "ANÁLISE COMPARATIVA DA PRESENÇA DO PAPILOMA VÍRUS HUMANO (HPV) NA MUCOSA ORAL E VAGINAL DE PACIENTES SOROPOSITIVAS PARA O VÍRUS HIV", de responsabilidade da Pesquisadora MARINA DE DEUS MOURA DE LIMA, sob orientação da Professora Doutora MARINA HELENA CURY GALLOTTINI DE MAGALHÃES.

Tendo em vista a legislação vigente, devem ser encaminhados a este Comitê relatórios anuais referentes ao andamento da pesquisa e ao término cópia do trabalho em "cd". Qualquer emenda do projeto original deve ser apresentada a este CEP para apreciação, de forma clara e sucinta, identificando a parte do protocolo a ser modificada e suas justificativas.

São Paulo, 04 de março de 2008

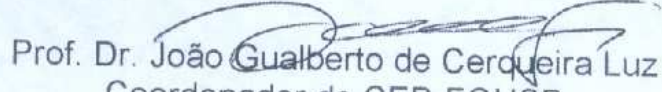

Coordenador do CEP-FOUSP 
ANEXO B - Termo de Consentimento Livre e Esclarecido

FACULDADE DE ODONTOLOGIA DA UNIVERSIDADE DE SÃO PAULO

TERMO DE CONSENTIMENTO LIVRE E ESCLARECIDO

$N^{\circ}$ de registro no CEP: Protocolo 177/07

Título: Análise comparativa da presença do papiloma vírus humano (HPV) na mucosa oral e de colo uterino de pacientes soropositivas para o vírus HIV

Pesquisadores responsáveis: Marina Helena Cury Gallottini de Magalhães, Catalina Riera Costa, Sõnia Maria Miranda Pereira, Marina de Deus Moura de Lima.

Instituição/Departamento: Faculdade de Odontologia - Universidade de São Paulo

Disciplina de Patologia Bucal

Telefone para contato: 30917902

Local da coleta de dados: Centro de Referência e Treinamento DST/AIDS

Prezada Senhora:

Você está sendo convidada a participar da pesquisa sobre a comparação da presença de Papiloma vírus humano (HPV) na boca e na mucosa do colo uterino. Sua participação não é obrigatória e a qualquer momento você pode desistir de participar e retirar seu consentimento. Sua recusa não trará nenhum prejuízo em seu atendimento ou em sua relação com o pesquisador. Para participar da pesquisa é necessário você dar o seu consentimento livre e esclarecido por escrito.

O papiloma vírus humano (HPV) aumenta o risco de desenvolvimento de câncer de colo de útero. O HPV está associado também com câncer de boca. Nosso interesse é descobrir se existe relação entre a presença deste vírus na região ginecológica e na boca. Primeiramente você irá responder a um questionário sobre sua saúde geral e oral. Depois terá sua boca examinada por uma dentista para avaliar sua saúde bucal. Em seguida, será feita a coleta de células superficiais da sua boca com uso de escova pequena e suave. Este procedimento é indolor e não causa ferimentos. A 
coleta vaginal, razão pela qual você veio ao ambulatório de Ginecologia do Centro de Referência e Treinamento DST-AIDS será feita pelo médico responsável do setor, conforme a rotina.

A participação não trará gastos a você e as informações obtidas poderão beneficiar você e outras pessoas, pois poderá fornecer informações sobre a presença e localização do vírus HPV. Se encontrarmos uma lesão em sua boca e suspeitarmos que ela possa ser causada pelo HPV, você será encaminhada para o tratamento adequado na clínica odontológica do Centro de referência e Treinamento DST/AIDS. Os procedimentos realizados durante o estudo serão inteiramente gratuitos.

Você receberá uma cópia deste termo. Os pesquisadores envolvidos poderão esclarecê-la a respeito de qualquer dúvida que porventura possa surgir. Basta ligar para Marina de Deus Moura de Lima (pesquisadora) ou para a $\operatorname{Prof}^{\mathrm{a}} \mathrm{Dr}^{\mathrm{a}}$ Marina Helena Cury Gallottini de Magalhães no telefone 3091-7902.

\section{Declaração de Consentimento}

Li ou alguém leu para mim as informações contidas nesse documento antes de assinar este termo de consentimento. Declaro que fui informado sobre os métodos do estudo e sobre os procedimentos de atendimento na clínica. Declaro que tive tempo suficiente para ler e entender as informações acima. Declaro também que toda a linguagem técnica utilizada na descrição desse estudo de pesquisa foi satisfatoriamente explicada e que recebi respostas para todas as minhas dúvidas. Confirmo também que recebi uma cópia deste formulário de consentimento. Compreendo que sou livre para me retirar do estudo em qualquer momento, sem perda de benefícios ou prejuízo do meu tratamento.

\section{DADOS DE IDENTIFICAÇÃO DO SUJEITO DA PESQUISA OU RESPONSÁVEL LEGAL}

\section{NOME DA PACIENTE}

DOCUMENTO DE IDENTIDADE №:

DATA NASCIMENTO:

ENDEREÇO:

BAIRRO: . CIDADE:

CEP: TELEFONE: DDD ) 
NATUREZA (grau de parentesco, tutor, curador etc.)

DOCUMENTO DE IDENTIDADE :

SEXO: $M \square F$

DATA NASCIMENTO.: 1

ENDEREÇO:

BAIRRO: CIDADE:

CEP:

TELEFONE: DDD

Assinatura da paciente ou responsável legal

Atesto que expliquei cuidadosamente a natureza deste estudo, junto ao participante e/ou seu representante autorizado. Acredito que o participante e/ou seu representante recebeu todas as informações necessárias, que foram fornecidas em uma linguagem clara e compreensível e que ele(a) compreendeu essa explicação.

Assinatura da Pesquisadora

Data: 
ANEXO C - Ficha sobre hábitos e comportamento sexual

ATENÇÃO - Essas informações são confidenciais e essa ficha será identificada apenas pelo número de inclusão, para preservar a privacidade do paciente.

Número de inclusão: Idade:

Cor de pele: Nível educacional:

Já teve doença sexualmente transmissível ? (Outra que não o HIV)

( ) $\operatorname{Sim}($ ) Não - Qual ? Quando?

Número de parceiros sexuais em toda vida maior ou igual a 5? ( )Sim （ )Não Número de parceiros sexuais nos últimos 6 meses( )0 ( )1 ( )2 ( )3 ( )4 ou mais Realiza sexo oral? ( )Sim ( )Não

Usa drogas injetáveis? ( ) Sim ( )Não

Fuma? ( )Sim ( ) Não

Há quanto tempo? ( )6 meses ou menos( )1 a 5 anos ( )5 a 10 anos ( )+10 anos Quantos cigarros por dia? ( ) menos de 1 maço ( ) 1 ( ) 2 ( ) 3 ( ) 4 ou mais Faz uso de bebidas alcoólicas? ( )Sim ( )Não

Com que freqüência: ( ) diária ( ) 3 vezes/semana （）2 ou menos/semana

Que bebida: ( ) cerveja ( ) destilados - cachaça, vodka, uísque

Dose/dia: ( ) 1-2 drinks ( ) 3-4 drinks ( ) 5 ou mais

Já tomou vacina para HPV: ( ) sim （ ) não

Está gestante? ( ) sim qtos meses ( ) não

Medicações em uso: 
ANEXO D - Ficha de dados clínicos e laboratoriais

Nome: $N^{0}$ inclusão:

Data da coleta:

Data do primeiro anti-HIV:

Provável meio de contaminação para o HIV: Sexual ( ); UDI ( ); Transfusão ( ); Vertical ( ); associação ( ) ; desconhecido ( ).

Terapia antiretroviral em uso: ( ) Sim ( ) Não Tipo: HAART( ) monoterapia( ) Outras ( )

Início de terapia antiretroviral (data) Tempo de terapia (meses)

Contagem de células CD4 (células/ $\mu l$ ) - última dosagem/data:

Carga viral do HIV (cópias/ml) - última dosagem/data:

Uso de outras medicações? Quais?

\section{Exame ginecológico:}

Lesão macroscópica sugestiva de infecção pelo HPV ( ) Sim （）Não

Diagnóstico final:

Presença de HPV pela captura híbrida （） Sim （） Não

Valor:

Risco de malignidade do HPV ( ) Alto risco ( ) Baixo risco

1

\section{Exame oral:}

Lesão oral sugestiva de lesão por HPV? ( ) Sim （ ) Não

Diagnóstico final:

Outras lesões ?

Presença de HPV pela captura híbrida? ( ) Sim ( ) Não

Valor:

Risco de malignidade do HPV ( ) Alto risco ( ) Baixo risco 